\title{
ВНИТИП - 90 ЛЕТ: УЧЕНЫЕ И ИСТОРИЧЕСКИЕ АСПЕКТЫ НАУЧНЫХ ИССЛЕДОВАНИЙ ОТРАСЛЕВОГО ИНСТИТУТА
}

Ефимов Д.Н., директор

Фисинин В.И., научный руководитель, академик РАН

ФГБНУ Федеральный научный центр «Всероссийский научно-исследовательский и технологический институт птицеводства» Российской академии наук (ФНЦ «ВНИТИП» РАН)

В первые годы Советской власти на развитие птицеводства было обращено большое внимание. В 1918-1920 гг. вышли Декреты «О племенном животноводстве», «Об обязательной поставке яиц» и «Об обязательной поставке домашней птицы». Эти документы - начало истории советского птицеводства.

В 1923 г. было организовано первое птицеводческое предприятие - совхоз «Горки-П». Затем создаются птицесовхозы «Степное гнездо», «Арженка», «Красный». В 1927-1928 гг. организуются первые ИПС и с их помощью - птицефермы в сельхозкоммунах, появляются и центры племенной работы - птицерассадники «Кучинский»и «Птичное» под Москвой, несколько позже «Пятигорский» на Северном Кавказе. В начале 30-х гг. начинают функционировать первые птицефабрики - Братцевская, Томилинская, Глебовская. Создание крупных по тому времени птицеводческих предприятий обусловило появление целого ряда проблем, требовавших обобщения и научной разработки. Необходимо было научно обосновать первый опыт работы птицехозяйств и разработать программу развития общественного птицеводства.

В 1930 г. Птицетрест Наркомзема РСФСР вносит предложение об организации Научно-исследовательского института птицеводства и назначает комиссию в составе А.С. Орлова, И.М. Канторовича и М.В. Орлова, которая должна была решить вопрос о размещении института, дать рекомендации по приглашению кадров и организации его экспериментальной базы. В октябре 1930 г. ВАСХНИЛ дает согла- сие на организацию Научно-исследовательского института птицеводства в г. Загорске Московской области.

Постановлением Коллегии Наркомзема СССР от 23 декабря 1930 г. в системе ВАСХНИЛ была утверждена сеть научно-исследовательских учреждений, в которую вошли НИИ птицеводства и зональные опытные станции: Псковская, Воронежская, Казанская, Шадринская, Омская, Северо-Кавказская, Каменец-Подольская, Ленинградская.

Научно-исследовательский институт птицеводства вместе с Московским зоотехническим институ-
Вифанский монастырь и духовная семинария (на территории будущего Птицеграда, вид с Вифанских прудов), 1920-1925rг том птицеводства и птицесовхозом №55 вошли в состав комбината, который разместился в местечке Вифания Загорского района. Фактически НИИ имел для своих лабораторий площадь около $300 \mathrm{~m}^{2}$, причем все лаборатории одновременно обслуживали и ВУЗ. В птицесовхозе №55 на 1 января 1931 г. было 10 тыс. кур, 148 уток и 144 гуся.

Институт птицеводства явился первым в стране научным учреждением, призванным разрабатывать вопросы селекции и племенного дела, физиологии, инкубации, кормления, технологии выращивания и содержания птицы всех видов, экономики и организации отрасли.

Очень важно было привлечь во вновь созданное научное учреждение ведущих ученых. И многие из них связали свою судьбу с институтом. Из Краснодара приехали профессор А.И. Дрбоглав и его ученики, специалисты по кормлению птицы и выращиванию молодняка И.Т. Маслиев и Н.Я. Квитко, из 


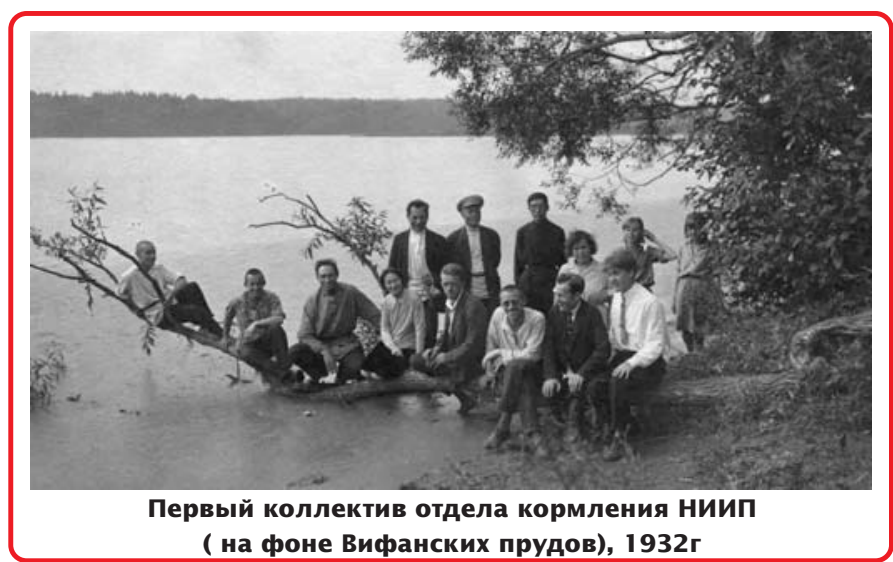

Ленинграда - профессор К.Н. Кржишковский и физиологи А.Р. Вальдман и Н.Г. Беленький, из Москвы - генетик С.Г. Петров, эмбриолог М.Д. Попов и другие. Некоторые совмещали работу в научном институте и ВУЗе. Так, в отделе кормления и на кафедре кормления работал И.Т. Маслиев, в отделе генетики и селекции и на кафедре генетики - С.Г. Петров, в отделе инкубации и на кафедре инкубации М.В. Орлов.

Научные разработки Института птицеводства 30-х гг. впечатляют и сегодня своей фундаментальностью и перспективностью. Ученые исследовали физиологию авитаминозов у птицы, проводили эксперименты по замене в рационах цыплят и уток животных белков белком сои, содержанию птицы в клеточных батареях.

Подробный анализ опубликованного в те годы материала со всей очевидностью показывает, что наши селекционеры уже тогда занимали передовые позиции по вопросам селекции и генетики в птицеводстве. Заведующий сектором генетики и селекции НИИП С.Г. Петров писал: «Имеется довольно большое количество методов селекции, могущих быть систематизированными следующим образом: а) селекция массовая; б) селекция семейная; в) селекция линейная; г) селекция синтетическая». Ученый рекомендовал «...иметь на рассаднике контрольную группу с отсутствием в ней селекционной работы или же группу с ведением селекции в обратном направлении». К сожалению, в те годы такое направление селекции не нашло поддержки, и только спустя 25 лет рекомендуемые методы стали широко применяться. На их основе впоследствии были созданы продуктивные отечественные кроссы птицы.

Уже в первые годы существования института его ученые закладывали базис будущего промышленного птицеводства страны. Достаточно указать, что в то время специалисты по технологии, кормлению, физиологии разрабатывали методы выращивания племенной птицы, откорма утят и цыплят на мясо в клеточных батареях. Сотрудник сектора кормления Ф. Гетц в сборнике работ института (1933) писал: «Опыт показал, что лучшим методом кормления утят в батареях является кормление сухими смесями, что дает возможность смело подойти к массовому откорму утят в батареях на мясо». В 1931 г. в птицесовхозе №55 - экспериментальной базе НИИП - уже имелся батарейный (клеточный) цех выращивания цыплят.

В 1932 г. в институте начала функционировать аспирантура. В числе первых выпускников были И.М. Шумилин, Н.П. Третьяков, Я.я. Шаповалов, Е.Т. Егошин, Н.В. Лобин.

Большую помощь работникам птицеводческих хозяйств и ферм оказывали учебные пособия и книги ученых института. Популярностью пользовались книги С.Г. Петрова «Генетика для птицеводов» (1933), К.Н. Кржишковского «Физиология сельскохозяйственных птиц» (1933), С.И. Сметнева «Фабрика цыплят» (1934). Коллективом авторов под руководством М.В. Орлова была написана книга «Техническое руководство по инкубации» $(1932,1934)$. Это оригинальная работа. Помимо описания конструкции инкубаторов и правил их эксплуатации, она содержала такие разделы, как «Биологические основы инкубации», «Биологический кон-

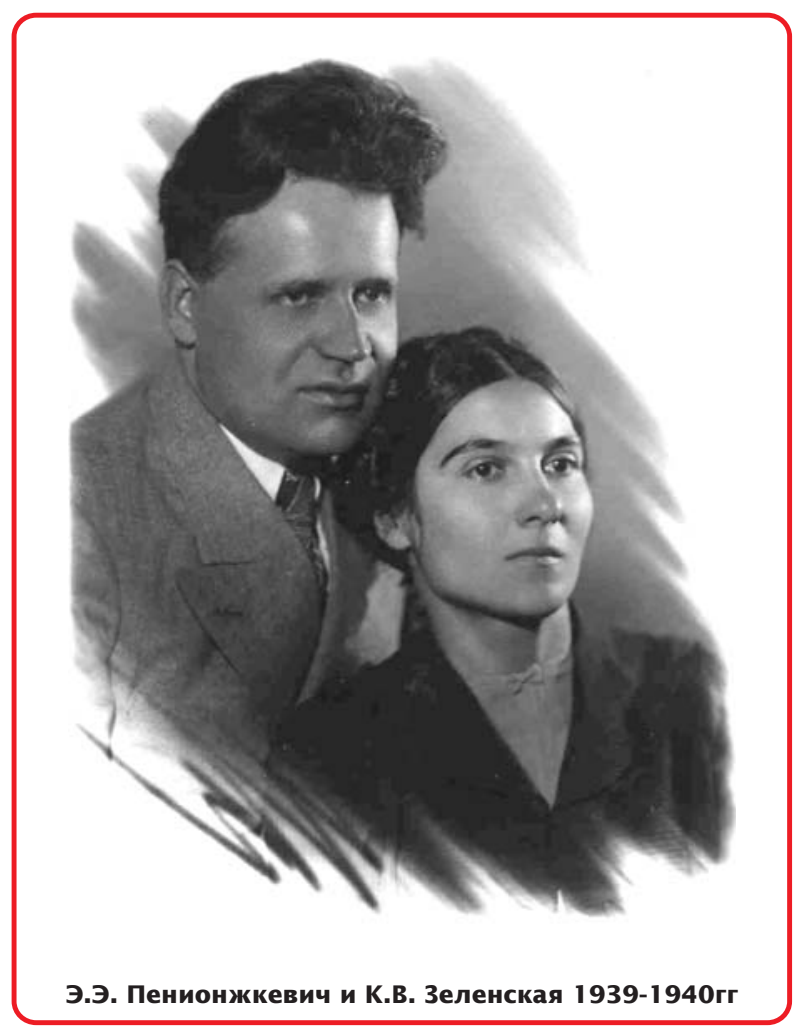


троль за процессом инкубации», «Анализ результатов вывода». Эти темы были разработаны впервые. Подобного биологически обоснованного руководства по инкубации яиц птицы ни в нашей стране, ни за рубежом не было.

В предвоенные годы ученые института начали разработку системы нормированного кормления птицы (И.Т. Маслиев, А.Р. Вальдман), методов биологического контроля за эмбриональным развитием во время инкубации (М.В. Орлов), селекции птицы (С.Г. Петров), содержания кур (С.И. Сметнев), определения пола у суточных цыплят (А.В. Плетнев), нормативов по труду (А.В. Колянинский).

В годы Великой Отечественной войны институт принимал участие в сохранении рассадников наиболее ценной племенной птицы, восстановлении хозяйств в освобожденных от фашистских оккупантов районах. Война привела почти полной смене кадров в птицехозяйствах. Необходимо было срочное обучение новых специалистов. Ученые института публикуют ряд книг: Э.Э. Пенионжкевич и другие - «Птицеводство» (1944, 1947), Н.П. Третьяков, Н.П. Федоровский - «Птица в домашнем хозяйстве» (1944), Э.Э. Пенионжкевич, К.В. Зеленская «Разведение и содержание гусей» (1944). В эти годы очень нужную работу вел художник НИИП Р.П. Коновалов. Им и его учениками изготавливались плакаты и муляжи-пособия по птицеводству, которые переда-

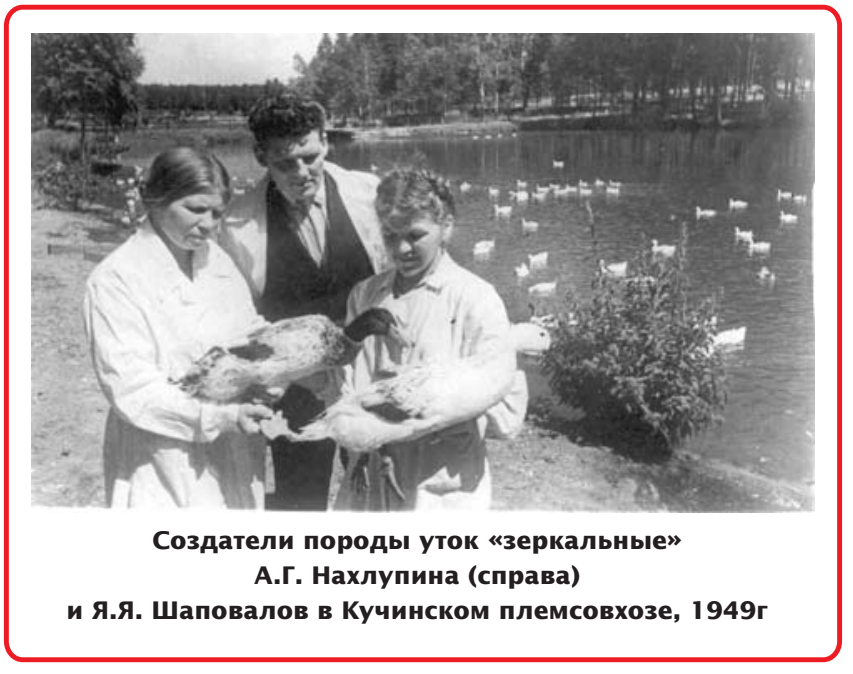

скрещиваниях.

Коллектив отдела кормления на основе экспериментальных работ и обобщения опыта передовых хозяйств разработал нормирование протеинового, минерального и витаминного кормления птицы в зависимости от ее вида и возраста. Была определена питательная ценность основных кормов, применяемых в птицеводстве, разработаны научные основы комбинирования кормовых средств и рецепты комбикормов для всех видов и возрастов птицы.

Развернулись также исследования технологии производства птичьего мяса. Обобщение опыта массового выращивания утят в Краснодарском крае и на Украине послужило основой для разработки комплекса мероприятий по развитию утководства в Казахской ССР и других районах страны. Были проведены эксперименты по интенсификации производства мяса уток и гусей, доказана возможность ликвидации сезонности продуктивного периода у уток и обеспечения круглогодового выращивания утят на мясо.

вались в совхозы и на ИПС.

В первую послевоенную пятилетку внимание ученых НИИП было уделено гусеводству, в частности, исследованию хозяйственных качеств холмогорских гусей; белковому питанию кур-несушек при их линьке; изучению обмена веществ у птицы под влиянием внешних температур; содержания витамина А в яйцах как индикатора их инкубационных качеств и другим вопросам.

В 1956 году институт был реорганизован во Всесоюзный (ВНИИП) и передан в ведение ВАСХНИЛ.

В 1950-60 гг. селекционеры института изучают наследование птицей продуктивных качеств, изменчивость признаков под влиянием отбора, определяют эффективность сочетаемости пород и линий при птицеводству: «Биологический контроль в инкубации» (Г.К. Отрыганьев, 1951), «Инкубация» (Н.П. Третьяков, 1953, 1957), «Племенная работа в птицеводстве» (Э.Э. Пенионжкевич, 1955), «Клеточное содержание кур-несушек» (И.Т. Маслиев, Г.К. Григорьев, 1957), «Утководство» под редакцией И.Т. Маслиева (1959), «Сельскохозяйственная птица» под редакцией Э.Э. Пенионжкевича (1962) и др.

Совершенно очевидно, что проблемы отрасли решались учеными института в тесном контакте со специалистами различных учреждений и ВУЗов. Большой вклад в развитие птицеводческой науки внесли М.Ф. Иванов, В.В. Фердинандов, М.И. Дьяков, Х.Ф. Кушнер, С.И. Сметнев, В.Ф. Ларионов, А.С. Солун, А.К. Данилова, С.И. Боголюбский, 
Н.В Пигарев, И.А. Патрик, П.Е. Божко, С.О. Пельтцер, Н.В. Дахновский и др.

Постановление ЦК КПСС и Совета Министров СССР №470 «Об организации производства яиц и мяса птицы на промышленной основе» (1964) ознаменовало новый этап в развитии отрасли. В целях улучшения научно-исследовательской работы в области птицеводства и разработки прогрессивной технологии содержания и выращивания птицы в промышленных условиях было принято решение создать при Птицепроме СССР Научный центр по птицеводству. В связи с этим Птицепрому СССР были переданы ВНИИП, реорганизованный во Всесоюзный научно-исследовательский и технологический институт птицеводства (ВНИТИП) и Ленинградский НИВИ, ныне Всероссийский научно-исследовательский ветеринарный институт птицеводства (ВНИВИП). Было организовано семь зональных опытных станций по птицеводству: Северо-Кавказская, Западно-Сибирская, Дальневосточная, Белорусская, Казахская, Закавказская и Прибалтийская.

Крупным событием для отечественной птицеводческой науки и практики было проведение в 1966 г. в Киеве XIII Всемирного конгресса по птицеводству, на котором зам. директора ВНИТИП, доктор биологических наук, профессор Э.Э. Пенионжкевич был избран президентом ВНАП. В работе по подготовке и проведению конгресса активно участвовали ученые вНИТИП.

В 1965-1970 гг. во ВНИТИП был проведен ряд исследований, имеющих теоретическое и практическое значение для дальнейшего развития птице-

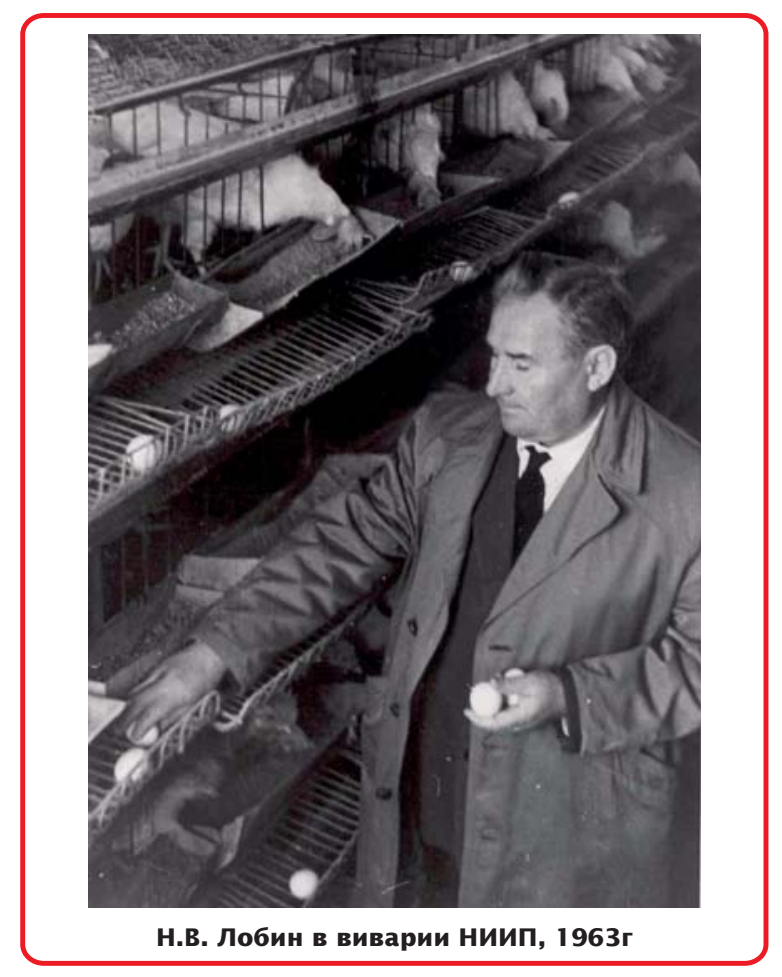

водства на промышленной основе. Так, отделами технологии производства яиц и мяса птицы были составлены рекомендации по выращиванию и содержанию яичных кур в клетках, организации производства мяса бройлеров, индеек, уток, гусей, ОСТы «Мясо бройлеров» и «Бройлеры для убоя». Разработан оптимальный комплекс условий выращивания бройлеров и ремонтного молодняка при ограниченном кормлении и содержания родительского стада (В.И. Коноплева, П.Н. Паньков, А.П. Волкова), технология круглогодового производства мяса гусей (П.Ф. Салеев), промышленного

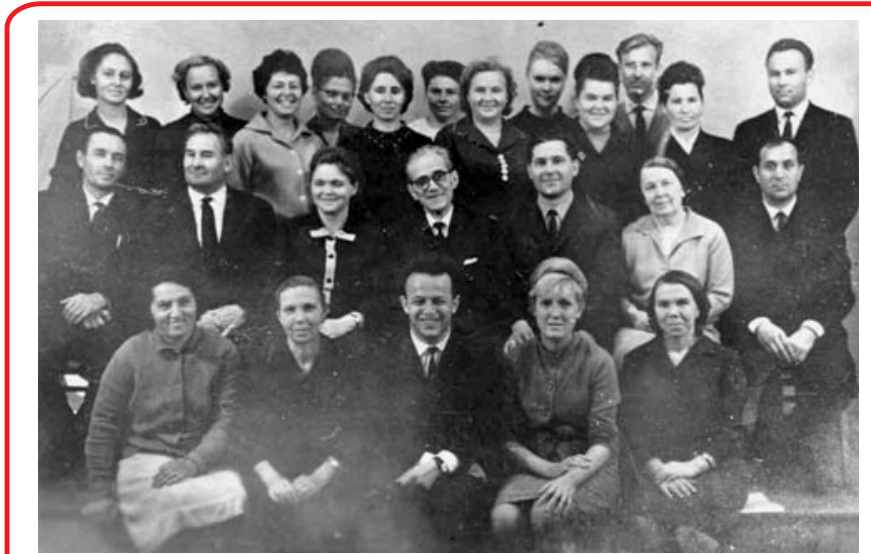

Коллектив отдела кормления Внитип. В верхнем ряду слева направо В. Благова, Т. Уласевич, Л. Купина, Н. Козлова, А. Смирнова, Г. Пажитнова, Л.Соловьева, Е. Устинова, Ю. Медведьева, В.Мальцев, А. Майорова, М. Норинский; в среднем В.Агеев, Н. Лобин, Г. Кирьянова, И. Маслиев, А. Шолков, О. Маслиева, П. Паньков; в нижнем ряду Т.Пименова, Н. Гордиенко, М. Гуревич, Н. Касаткина, Р. Иванова, 1966г

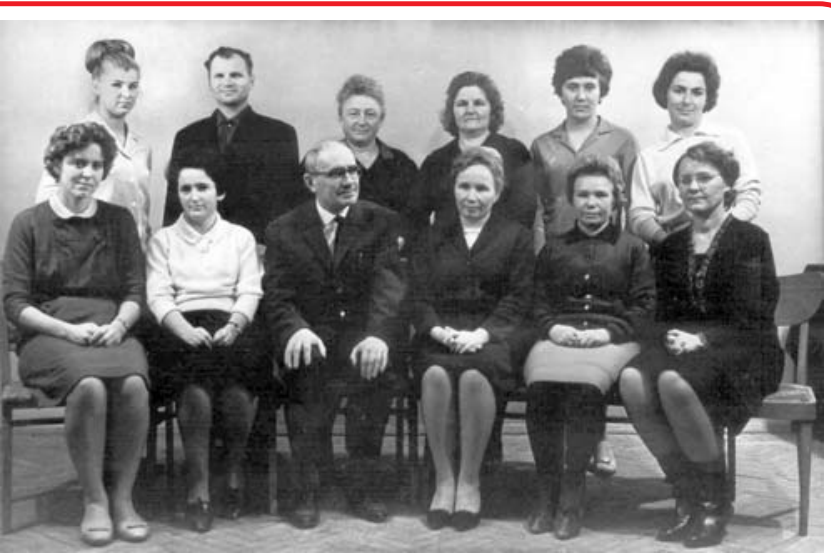

Коллектив отдела инкубации внитип.

Стоят - В.Н. Марцева, Ю.В. Исаев, Ю.Н. Владимирова, Н.Е. Хизова, Л.В. Алфутина, Н.А. Юхачева; сидят - Р.А. Салеева, Л.Н. Агеева, Г.К. Отрыганьев, А.М. Сергеева, В.С. Салагина, А.Ф. Отрыганьева, 1967г 


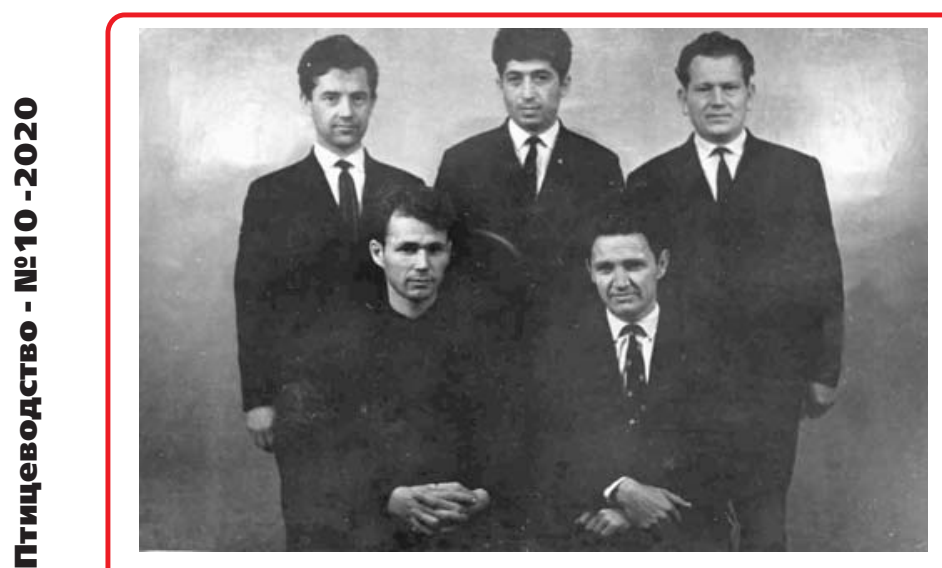

Молодые ученые ВНИТИП. Сидят Э.К. Силин, Э.А. Дуюнов; стоят Ю.А. Банько, Г.А. Тардатьян, С.А. Воробьев, 1967

производства индюшат-бройлеров, метод раздельного по полу выращивания индюшат (Т.А. Столляр, Ф.Ф. Алексеев).

Отделом биологии и технологии размножения птицы разработана принципиально новая боксовая технология инкубации.

В отделе селекции и генетики проводилась в больших масштабах работа по акклиматизации завезенных из-за рубежа линий кур. В частности, в ГППЗ «Маркс» Саратовской области ученые и специалисты занимались выведением сочетающихся линий кур породы белый леггорн. Был разработан первый в стране селекционный план, основанный на современных методах оценки производителей и линий и их совершенствования, ускорении темпов селекции, сокращении интервалов между поколениями и т. д. Внедрение его на заводах обеспечило получение от кур-несушек чистых линий по 269 яиц в год и от гибридов по 270-273 яйца за 11 мес.

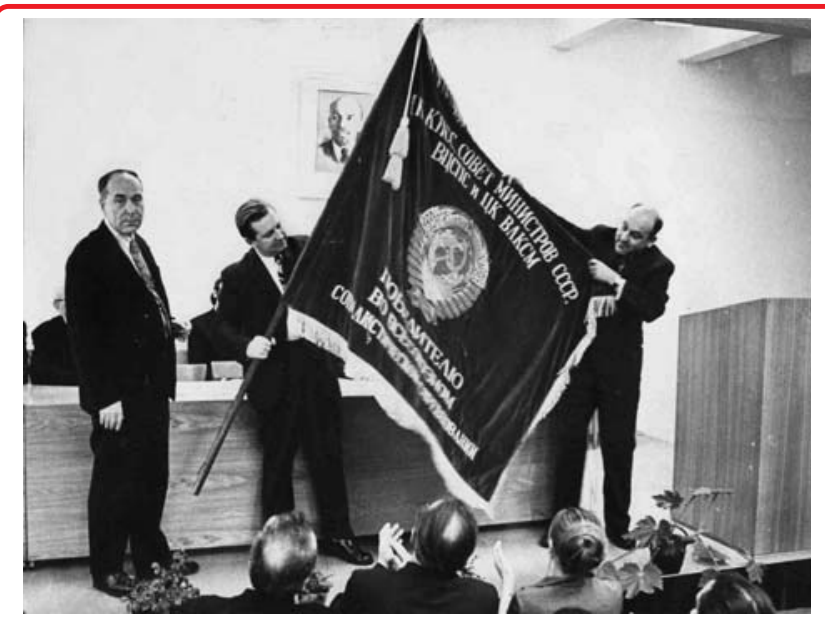

И.А. Бахтин, В.И. Фисинин, Т.А. Столляр во время вручения переходящего Красного знамени ЦК КПСС, Совета Министров СССР, ВЦСПС, ЦК ВЛКСМ коллективу ВНИтИП - победителю во Всесоюзном социалистическом соревновании, 1975г
Этот период для птицеводства характеризуется переходом на сухой тип кормления птицы. Отделом кормления ВНИТИП и кафедрой птицеводства ТСХА разработаны рекомендации по оценке и нормированию кормов для сельскохозяйственной птицы по комплексу питательных веществ и обменной энергии, рецепты полнорационных комбикормов и комбикормов-концентратов для яичной и мясной птицы.

70-е гг. стали периодом коренной перестройки деятельности ВНИТИП как головного научного учреждения отрасли. Этому во многом способствовали новая форма работы по заказам-заданиям Птицепрома СССР, тесная взаимосвязь института с республиканскими и областными трестами Птицепром.

На этапе становления промышленного птицеводства России важную роль в повышении квалификации кадров играли народные университеты по птицеводству. В 1972 г. работало 46 народных университетов по птицеводству, в которых с лекциями выступали ученые ВНИТИП и других координируемых НИИ и ВУЗов.

Наиболее крупные народные университеты: Московский при областном управлении птицефабрик (Б.И. Скрибачилин, В.С. Крылов, А.А. Заболотников), Ленинградский (В.С. Чаус), Омский (Л.К. Новицкий), Кемеровский (В.Т. Дикунов), Краснодарский (И.В. Москвич), Ростовский (И.И. Мисиков), Вологодский (М.С. Танин), Оренбургский (В.С. Малышев), Ставропольский (В.И. Постников) и др.

Научное обеспечение работы народных университетов осуществляли ученые НИУ и ВУЗов: ВНИТИП - Г.А. Тардатьян, К.В. Злочевская, Э.К. Силин, Р.И. Варакина, В.Н. Березнев, Я.С. Ройтер, А.М. Сергеева, В.И. Коноплева, А.Д. Давтян, В.Н. Агеев, И.А. Егоров, Л.В. Шахнова, А.П. Волкова, В.М. Селянский, К.И. Карюкина, Т.А. Столляр, П.Ф. Салеев, М.А. Асриян, Т.М. Околелова и др.; ВНИВИП Р.Н. Коровин, А.Н. Борисенкова, Ф.С. Кудрявцев, Л.Л. Погребняк и др.; ТСХА - С.И. Сметнев, Н.В. Пигарев, С.О. Пельтцер; МВА - А.К. Данилова, А.С. Солун, М.С. Найденский, Б.Ф. Бессарабов; Ленинградский СХИ - С.И. Боголюбский, П.П. Царенко; ВНИИГРЖ И.Л. Гальперн; ВНИИПП - И.А. Патрик, М.Д. Пигарева, Е.Г. Шумков, журнал «Птицеводство»- М.Н. Богданов и др.

Значительно расширились связи института с конструкторскими бюро и проектными организациями (ГСКБ завода «Пятигорсксельмаш», КБ объединений «Звенигород» и «Птицепром-оборудование», 
ЦНИИЭПтицепром, Росгипрониисельхоз и др.). Для успешного решения глубоких теоретических вопросов по биологии сельскохозяйственной птицы ВНИТИП выполняет совместные работы с институтамИ АН СССР, АМН СССР и ВАСХНИЛ.

В институте значительно активизировалась изобретательская работа. Так, за 1976-1980 гг. ему было выдано 50 авторских свидетельств на изобретения в области птицеводства.

Период 1970-1980 гг. для ВНИТИП характеризуется значительным ростом не только количественных, но и качественных показателей научных исследований, направленных на выполнение основной задачи - получение максимального количества продукции с единицы производственной площади. В частности, была разработана технология содержания яичных кур родительского стада в механизированных клеточных батареях, обеспечивающая получение инкубационных яиц. В настоящее время по этой технологии содержат 99\% родительского поголовья яичной птицы.

Разработаны и внедрены в производство рекомендации по выращиванию мясных цыплят, индюшат и цесарят в клеточных батареях, утят и гусят на сетчатых полах, применению принудительной линьки для кур родительского стада бройлеров, световым режимам для индюшат.

На основе разработок института и других учреждений налажено серийное производство клеточных батарей КБР-2 для яичных кур родительского стада, БКН-3 для кур промышленного стада, БКМ-3 и БКМЗБ для ремонтного молодняка и бройлеров, 2Б-3 для бройлеров.

Отделами технологии производства яиц и мяса птицы, механизации, экономики, ветеринарии и физиологии разработаны общесоюзные нормы технологического проектирования птицеводческих предприятий (совместно с ЦНИИЭПтицепром, ВНИВИП и ВНИВС).

В 1977 г. сотрудники отдела селекции и генетики ВНИТИП совместно со специалистами ГППЗ «Маркс» создали первый отечественный кросс яичных кур «Старт», а в 1982 г. с учеными ВНИИГРЖ и специалистами ГППЗ «Конкурсный» и «Смена» Московской области, «Большевик» Ленинградской области кросс мясных кур «Бройлер-6». Учеными отдела селекции и генетики ВНИТИП разработаны и переданы производству методические рекомендации по селекции мясных кур на увеличение выхода цыплят, селекционно-племенной работе с птицей кросса
«Бройлер-6», по работе с индюками для получения от них спермы в специальном боксе, использованию новых сред A-5 и А-7 для разбавления и хранения спермы сельскохозяйственной птицы, организации селекционной работы с четырехлинейными мясными кроссами кур. Разработан комплексный план селекционной работы с птицей до 2000 г., программы обработки селекционных данных на ЭВМ. Вычислительный центр ВНИТИП на хоздоговорных началах выполняет обработку селекционных материалов восьми племптицезаводов страны.

За успехи, достигнутые в разработке и внедрении достижений науки, ВНИТИП 19 февраля 1976 г. Указом Президиума Верховного Совета СССР был награжден орденом Трудового Красного Знамени.

В 1978 г. по приказу Минсельхоза СССР в целях координации и научного руководства селекционной работой в стране во ВНИТИП создан селекционный центр (руководитель К.В. Злочевская), который осуществлял научно-методическое руководство по вопросам селекции 12 научных учреждений и координировал работу 23 учреждений.

Хочется особо подчеркнуть в этот период первые успехи ученых-селекционеров Северо-Кавказской, Белорусской, Казахской, Западно-Сибирской, Прибалтийской зональных опытных станций, создавших породу северокавказских индеек, кроссы яичных кур «Беларусь-9», «В63», «Волжский-3», «Янтарь», кросс уток «Медео».

На основе научных разработок ВНИТИП по кормлению птицы был утвержден ГОСТ 18292-72 «Комбикорма полнорационные для сельскохозяйственной птицы». Это был первый в стране стандарт на комбикорма для птицеводства. Разработаны и широко использовались в производстве методические рекомендации по кормлению цыплят-бройлеров при раздельном по полу выращивании в клетках, профилактике стресса у кур, определению витаминов A, Е и каротиноидов в кормах, препаратах и биологических обьектах, использованию известняков в рационах для сельскохозяйственной птицы, методическое руководство по оценке и испытанию комбикормов и премиксов.

За разработку и внедрение в промышленное птицеводство системы нормированного кормления, обеспечивающей высокую про-дуктивность птицы и эффективное использование корма, коллективу ученых ВНИТИП и ряда научных учреждений в 1979 г. присуждена премия Совета Министров СССР.

За 1976-1979 гг. сотрудниками института по пла- 
ну МСХ СССР внедрено 58 разработок, из них восемь - по авторским свидетельствам; по хоздоговорной тематике выполнено 106 тем.

В этот период вышли следующие книги ученых института: В.М. Селянский «Анатомия и физиология сельскохозяйственной птицы» (1972), В.Н. Агеев «Кормление высокопродуктивных яйценоских кур» (1973), А.М. Громов, Я.С. Ройтер «Цесарки» (1975), О.И. Маслиева «Витамины в кормлении птицы» (1975), Г.К. Отрыганьев, А.Ф. Отрыганьева «Технология инкубации» (1975), Н.В. Лобин, П.Ф. Салеев «Продуктивное гусеводство» (1975), А.Ф. Спиридонов, Г.А. Тардатьян «Промышленный утководческий комплекс» (1976), И.П. Кривопишин «Озон в промышленном птицеводстве» (1979), «Промышленное птицеводство» (составители В.И. Фисинин и Г.А. Тардатьян, 1978), «Технология производства яиц на промышленной основе» (составитель Н.И. Старчиков, 1978) и другие.

В соответствии с договорами о научно-техническом сотрудничестве ученые ВНИТИП проводили совместные исследования по птицеводству с учеными ГДР, ЧССР, СФРЮ, Республики Куба.

В 80-х гг. были отселекционированы две гетерогенные популяции, послужившие основой для белоскорлупного кросса кур «П-46» (авторы Р.И. Варакина, С.Н. Фузеева, К.В. Злочевская и др.). От несушек этого кросса в хозяйствах за год получали по 280-285 яиц, и он с успехом использовался во многих регионах.

В 1992 г. селекционерами ВНИТИП и специалистами ГППЗ «Пачелма» был создан кросс кур «Прогресс» (авторы А.П. Кириченко, К.В. Злочевская, А.А. Севастьянова и др.), а спустя 3 года специалистами ГППЗ «Свердловский» и учеными института - кросс «Родонит» (Г.П. Грачева, А.П. Безусова, В. И. Фисинин, Т.А. Хмельницкая и др.).

Исходным материалом для этого четырехлинейного кросса послужила птица кросса «Ломанн». Гибридные несушки, а также куры исходных линий имели высокие яйценоскость (290-315 шт.) и массу яиц (64-65 г). Материнская форма Р34 аутосексна по скорости роста пера у цыплят, а гибридные петушки и курочки различаются по цвету оперения. Точность сексирования достигает 99\%. Кросс «Родонит» был широко внедрен в стране.

Большая работа по селекции мясных кур проведена ГППЗ «Смена» совместно с ВНИТИП. В 1988 г. был утвержден четырехлинейный кросс «Смена» (авторы Л.И. Тучемский, Г.В. Гладкова, Е.А. Безусов, В.И. Фисинин, И.В. Журавлев, Б.Ф. Авдонин и др.). В 7-недельном возрасте бройлеры этого кросса весили 2,1 кг, конверсия корма составила 2,2 кг/кг. В 1992 г. авторские свидетельства на четырехлинейный кросс «Конкурент», созданный совместно со специалистами ГППЗ «Конкурсный», получили научные сотрудники института Л.В. Шахнова, Л.С. Карпенко, Л.Н. Звонова, Т.Г. Исаева. Живая масса 7недельных цыплят этого кросса достигала 2,2 кг, затраты корма на 1 кг прироста - 2,24 кг. В том же году в ГППЗ «Еткульский» была закончена работа по селекции кросса кур «Урал». Наряду со специалистами завода, в его создании активно участвовал ученый ВНИТИПЭ.К. Силин.

Большую работу ВНИТИП вел и с другими видами мясной птицы. На базе ГППЗ «Благоварский» усилиями ученых и практиков отселекционирован двухлинейный кросс уток «Благоварский-12» (1998), новая отечественная порода гусей «Линдовская» (авторы Я.С. Ройтер, специалисты Линдовской птицефабрики) и две экспериментальные линии на племзаводе «Прииртышский» Омской области.

Дальнейшему росту объемов производства яиц и мяса птицы способствовала созданная интегрированная система обеспечения отрасли племенной продукцией: племзавод-репродуктор I порядка, репродуктор II порядка, товарные птицехозяйства, ИПС

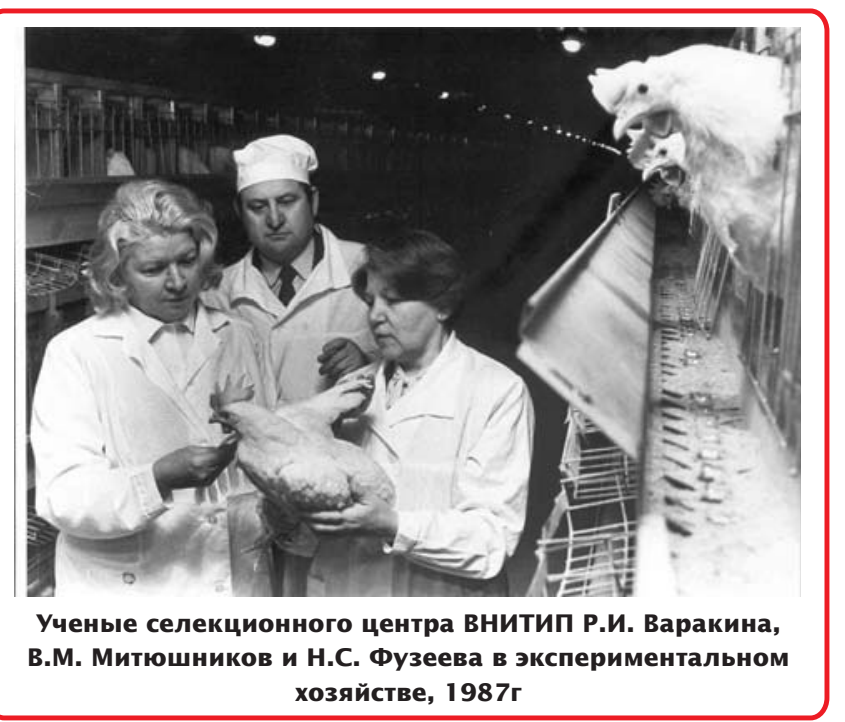
и ЛПХ населения. В высокой конкурентоспособности отечественного птицеводства важнейшее место занимала наука. В этот период созданы и масштабно внедрены новые яичные $и$ мясные кроссы кур (Старт23, П-46, Волжский-3, Заря17, Прогресс, Смена, Бройлер-6, СК Русь, Конкурент и др.). В 1984 г. авторскому коллективу (К.В. Злочевская, Л.В. Шахнова, М.В. Орлов, Э.К. Силин, С.И. Бо- 
голюбский, Л.И. Тучемский, М.Н. Анненкова, И.Л. Гальперн и др.) была присуждена премия Совета Министров СССР «За разработку и внедрение методов создания отечественных кроссов яичных и мясных кур, системы организации производства гибридной птицы в стране».

Основная база создания новых кроссов - экспериментальные хозяйства ВНИТИП, зональные опытные станции, ведущие племенные заводы («Смена», «Конкурсный», «Большевик», «Россия», «Птичное», «Лабинский», «Свердловский», «Маркс», «Пачелма», «Кучинский», «Хабаровский», «Новосибирский»).

В 1990 г. ученым ВНИТИП и специалистам племзаводов было присвоено звание Лауреатов премии Совета Министров СССР за работу «Создание и внедрение в производство высокопродуктивных кроссов яичных и мясных кур» (Б.Ф. Авдонин, Р.И. Варакина, И.В. Журавлев, К.В. Злочевская, В.М. Митюшников, В.И. Фисинин, Н.С. Фузеева, В.С. Сидоров, Г.В. Гладкова, Е.А. Безусов, Л.М. Кузнецова, Л.И. Тучемский, М.Н. Анненкова, Ф.Г. Праксин).

В этом же году за научную разработку новых технологий в мясном птицеводстве премия Совета Министров СССР присуждена ученым ВНИТИП Г.А. Тардатьяну, Н.С. Ковацкому, А.Д. Давтяну и др.

чтобы кратко охарактеризовать научно-информационный вклад ученых ВНИТИП в обеспечение отрасли с 1980 по 1990 гг. назовем две цифры: издано 34 книги и 60 методических рекомендаций. Книги: Ю.Я. Марков «Принудительная линька курнесушек» (1981); М.В. Орлов, Э.К. Силин «Разведение кур» (1981); К.И. Карюкина, Л.Л. Горшков, Г.В. Красноярцев «Организация снабжения и сбыта в птицеводстве» (1982); П.Ф. Салеев «Промышленное гусеводство» (1982); В.И. Фисинин, И.В. Журавлев, Т.Г. Айдинян «Эмбриональное развитие птицы» (1990); Т.М. Околелова «Кормление сельскохозяйственной птицы» (1990) и др. Методические рекомендации: В.И. Фисинин, Т.А. Столляр, Е.С. Пархоменко, В.Т. Скляр, Л.Н. Агеева, И.А. Бахтин, Л.К. Новицкий, Л.А. Михеева, Р.А. Горбунов «Технология выращивания бройлеров на сетчатых полах» (1979);К.И. Карюкина, Л.Л. Горшков, А.М. Кобзева «Методические рекомендации по организации производственных объединений в птицеводстве» (1981); Г.К. Отрыганьев, Ю.В. Исаев, Л.Ф. Дядичкина «Рекомендации по диагностике причин эмбриональной смертности сельскохозяйственной птицы» (1982); Р.И. Варакина, А.Д. Давтян, И.В. Жу- равлев, К.В. Злочевская и др. «Рекомендации по племенной работе с птицей на племзаводах и в племенных хозяйствах-репродукторах» (1983); Т.А. Столляр, Л.Ф. Самойлова, В.И. Коноплева «Методические рекомендации по нормированию и режимам ограниченного кормления ремонтного молодняка и кур родительского стада бройлеров» (1984); В.С. Лукашенко, М.А. Лысенко, Г.Н. Лысенко, Т.А. Столляр «Методические рекомендации по проведению анатомической разделки и органолептической оценки качества мяса сельскохозяйственной птицы» (1984); Г.А. Тардатьян, П.Ф. Салеев, Н.С. Ковацкий «Рекомендации по технологии выращивания и содержания мускусных уток» (1984); Ф.Ф. Алексеев, Ю.А. Белозеров, С.А. Воробьев и др. «Технология производства мяса индеек» (1987); В.И. Ермакова, И.А. Егоров, и др. «Рекомендации по применению травяной муки в кормлении сельскохозяйственной птицы» (1989); В.И. Филоненко, В.Г. Шоль, «Методические рекомендации по применению электроактивированной воды в производстве мяса бройлеров» (1990) и др.

1990-й год для птицеводства был юбилейным исполнилось 25 лет системе Птицепрома России. Этот двадцатипятилетний период был весьма результативным, в это время произошли глубокие изменения, позволившие перейти от примитивных к научно-обоснованным методам ведения интенсивного птицеводства, которое хорошо корреспондировалось с мировым опытом.

В 1990 г. в состав Птицепрома РСФСР входило 73 республиканских, краевых и областных объединений, в них в общей сложности 850 птицефабрик и около 400 ИПС. В республике насчитывалось 18 племенных заводов, 76 племенных репродукторов первого и второго порядка. На долю государственных хозяйств приходилось 93\% валового сбора яиц и 97\% производства птичьего мяса.

Распад СССР в 1991 г. привел к катастрофическим последствиям в промышленности и сельском хозяйстве и, в том числе, в птицеводческой отрасли. 1991-1997 гг. - это кризис отрасли. По стране прокатилось ельцинско-гайдаровское торнадо - смерч невероятной разрушительной силы. Начался настоящий кризис - банкротство отрасли, о чем свидетельствуют следующие статистические данные. Производство мяса птицы в убойной массе (тыс. т) в 1991 г. составляло 1751 , в том числе, в сельхозпредприятиях - 1172, а в 1997 г. соответственно - 630 и 373. Если в 1991 г. на душу населения производи- 
лось 12 кг отечественного мяса птицы, то в 1997 г. 4,3 кг. Доля импорта глубокозамороженного мяса птицы («ножек Буша») в 1997 г. достигла 64,5\%. В кризисный период производство мяса бройлеров прекратилось в 16 субъектах России. Производство яиц в 1991 г. составляло 46,9 млрд. шт. в том числе в сельхозпредприятиях - 36,5 млрд. шт., на душу населения производилось 320 яиц; в 1997 г. эти показатели составили соответственно: 32,2 и 22,3 млрд. шт. и 215 яиц на душу населения.

Кризис характеризовался отсутствием нормативно-правовой базы, позволяющей оперативно проводить регулирование продовольственного рынка и обеспечивать необходимую ценовую конкуренцию отечественной продукции.

В неимоверно трудных условиях в этот период находился ВНИТИП и координируемые им НИУ, ученые получали мизерные зарплаты, с задержкой в три-четыре месяца, но продолжали работать на отрасль. Хочется отметить, что именно в этот трудный период усилилась хоздоговорная деятельность отделов института. Как пример можно привести работу лаборатории биохимического анализа по контролю качества кормов, кормовых добавок, инкубационных яиц для десятков птицеводческих хозяйств различных регионов России. Руководил отделом физиологии и биохимии в этот период профессор А.Н. Тишенков. Коллектив отдела с привлечением ученых других лабораторий ВНИТИП разработал для зоолабораторий птицефабрик и племпредприятий руководство по оценке качества кормов, органов, тканей, яиц и мяса птицы.

В этот кризисный период ученые ВНИТИП работали в тесном контакте с межрегиональными научнотехническим центром (МНТЦ) «Племптица», Росптицепромом и многими птицефабриками страны. Важная работа ученых в этот период была посвящена организации функционирования производственных и научно-производственных систем в птицеводстве. В 1994 г. были подготовлены «Рекомендации по организации и функционированию производственных и научно-производственных систем в птицеводстве», которые утвердил научно-технический совет МНТЦ «Племптица» Российской академии сельскохозяйственных наук. Рекомендации подготовили И.М. Попов, Л.Д. Горяинова, В.И. Фисинин (ВНИТИП), М.А. Гробова, Н.А. Кравченко, Ю.Я. Марков, В.К. Онисовец, В.Е. Попов (МНТЦ «Племптица»), Г.А. Бобылева и А.А. Супрунов (Росптицепром). При подготовке рекомендаций использовали опыт дея- тельности птицеводческих научно-производственных систем «Смена» (Л.И. Түчемский), «Конкурсный» (Е.С. Елизаров), «Загорск» (В.С. Сидоров), «Свердловский» (Г.П. Грачева), «Птичное» (Ю.В. Косинцев), «Большевик» (Н.С. Шубин), «Русь» (В.В.Слепухин), «Красный Кут» (В.И. Штода), «Сибирь» (Л.К. Новицкий) и др.

Наиболее активно в этот период работали бройлерная научно-производственная система «Смена», а по яичной птице - «Свердловский». Советы систем проходили, как правило, два раза в год по 2-3 дня, где совместно с учеными ВНИТИП рассматривали деятельность птицефабрик и репродукторов систем, анализировали показатели хозяйств, результаты внедрения научных разработок, опыт отдельных хозяйств по зоотехнии и ветеринарии. Заслушивали отчеты директоров предприятий, доклады ученых ВНИТИП, ВНИВИП, ВНИИПП, а также представителей зарубежных компаний. Производственные системы издавали типографским способом «Опыт работы производственной системы». Ученые НИУ и специалисты головных предприятий системы в течение года выезжали с консультациями непосредственно в хозяйства в различные регионы России.

Важным направлением работ в этот период явилось проведение конкурсных испытаний бройлерных кроссов в 1993-1997 гг. под эгидой МНТЦ «Племптица» и ВНИТИП в госплемзаводах «Смена», «Конкурсный» Московской области, в экспериментальном хозяйстве ТСХА, на птицефабрике «Чайковская» Пермской области. В конкурсах участвовали: ЭПХ Западно-Сибирской ЗОСП, ГППЗ «Красный Кут», «Большевик», «Русь», «Смена», «Конкурсный», «Еткульский», «Катайский». На конкурсах оценивались зоотехнические показатели и мясные качества отечественных бройлеров.

В 1995 г. Указом Президента Российской Федерации за сохранение и рациональное использование генетических ресурсов кур ученым ВНИТИП (Н.С. Горбачевой, К.В. Злочевской, А.А. Севастьяновой, Э.К. Силину, Н.С. Фузеевой, В.И. Фисинину) и ВНИИГРЖ (И.Л. Гальперн, И.А. Пароняну) была присуждена Государственная премия Российской Федерации в области науки и техники. Дипломы и значки Лауреатов Государственной премии вручил в Кремле Президент России Б.Н. Ельцин.

Следует отметить, что в настоящее время генетическая коллекция кур в Загорском ЭПХ ВНИТИП включает 76 пород и является крупнейшей в Западной Европе. 
В период 1991-1997 гг. учеными ВНИТИП был издан ряд методических рекомендаций для птицеводческих хозяйств страны: Т.М. Околелова, И.А. Егоров, В.С. Крюков, И.П. Байковская и др. «Обогащение комбикормов новыми биологически активными и минеральными веществами» (1992); И.А. Егоров, Н.Я. Чеснокова, Г.В. Игнатова, А.В. Езерская «Использование лизина в комбикормах для птицы» (1993); И.А. Егоров, Л.Я. Купина, Т.Н. Ленкова, Р.Н. Муртазаева, Л.В. Топорова и др. «Использование метионина В комбикормах сельскохозяйственной птицы» (1994); Т.А. Столляр, В.С. Лукашенко, М.А. Лысенко, В.И. Филоненко, Л.Ф. Самойлова, А.Н. Шевяков и др. «Технология выращивания крупных мясных цыплят для глубокой переработки мяса» (1994); Р.И. Варакина, К.В. Злочевская «Программа по работе с кроссом яичных кур «П 46» (1995); Т.М. Околелова, Э.В. Удалова и др. «Включение комплексных ферментных препаратов в комбикорма с повышенным содержанием трудногидролизуемых компонентов» (1996); И.А. Егоров, П.Н. Паньков, В.П. Куренева, Т.Н. Ленкова и др. «Использование нетрадиционных кормов в птицеводстве» (1996); А.Ш. Кавтарашвили, И.А. Егоров, Ш.А. Имангулов, В.Т. Скляр, В.С. Лукашенко, Л.Ф. Дядичкина и др. «Ресурсосберегающие технологии производства яиц» (1997) и др.

Анализируя этот кризисный для отрасли этап, хотелось бы особо подчеркнуть огромную созидательную роль научных учреждений, директорского корпуса птицепредприятий, специалистов, рабочих коллективов в сохранении и последующем восстановлении российского птицеводства.

Период 1998-2002 гг. - это начало возрождения отечественного птицеводства. Кризисные явления в России привели к резкому снижению производства птицепродуктов, однако и на этом этапе развития отрасль осталась реальным источником пополнения продовольственных ресурсов в стране.

В 1999 г. среднее потребление яиц и яйцепродуктов на душу населения в России составило 227 шт., а потребление мяса птицы - около 10 кг. Импорт продовольствия в сложившейся в АПК России ситуации усугубил экономические и социальные проблемы. В 1998 г. было завезено продовольствия на сумму 11,5 млрд. долларов, причем 75\% приходилось на Дальнее Зарубежье. В данный период это была самая крупная статья оттока капитала за границу. Выход из создавшегося положения был реально один - восстановление и интенсивное развитие отечественного производства продовольствия за счет массированного вложения первоочередных инвестиций в мясопроизводящие отрасли - птицеводство и свиноводство.

На 1 января 1999 г. в стране функционировало 670 яичных птицефабрик, в том числе работающих на полную проектную мощность - 74 (11\%), на 50\% проектной мощности - 168 (25\%), ниже 50\% - 391 (58,4\%), пустующих хозяйств и фрабрик - 37 (5,6\%). В мясном птицеводстве на указанную дату в России имелась 151 крупная бройлерная фабрика, из которых только 18 работали на полную проектную мощность (1 1,9\%), на 50\% мощности - 30 фабрик (19,8\%), менее 50\% мощностей - 57 птицефабрик (37,8\%), и неработающих - 46 фабрик (30,5\%).

Рынок мяса птицы заполонили так называемые «ножки Буша». Импорт бройлерного мяса в 1998 г. достиг 1 млн. 32 тыс. т, а в 2002 г. - 1 млн. 432 тыс. т.

С 1998 г. птицеводство вышло на небольшую, но положительную динамику роста. Особо хочется подчеркнуть огромную роль в данном процессе руководителей и специалистов птицехозяйств, коллективов ученых ВНИТИП, ВНИИПП, ВНИВИП и др. Следует признать, что к этому времени произошла своеобразная «адаптация», прошла растерянность и хозяйственный шок, характерные для начала 90-х годов. Несомненно, что росту производства в большой степени способствовало создание и широкое внедрение в хозяйствах отечественных высокопродуктивных кроссов мясной и яичной птицы («Смена-2», «Конкурент-2», «Русь», «Барос», «Сибиряк», «Родонит», «П-46», «Кубань-123»), эфффективная творческая работа производственных и научно-производственных систем как координаторов внедрения в отрасли новых научных разработок. Значительно выросли показатели продуктивности птицы по сравнению с 1990 г. (среднесуточные приросты живой массы бройлеров 35-45 г, продуктивность яичных кур 290-320 яиц).

Лидером в отечественном мясном птицеводстве на этом этапе развития был кросс «Смена-2», удельный вес которого в общем объеме производства мяса бройлеров в 1999 г. составлял 47\%.

Высокопродуктивный яичный аутосексный кросс «Родонит», созданный специалистами племзавода «Свердловский» и учеными ВНИТИП, занимал 45\% в производстве яиц в системе Росптицепрома.

В ноябре 1998 г. во ВНИТИП состоялось координационное совещание по птицеводству «Наука и развитие мирового и отечественного птицеводства на 
пороге XXI века», в котором приняли участие 65 научных организаций РФ и СНГ, работавших над выполнением заданий сводного плана по созданию конкурентоспособных кроссов птицы, ресурсосберегающих технологий производства и переработки птицеводческой продукции. Надо признать, что сегодня координационная деятельность в большей степени утрачена и требует восстановления. В 1999 г. ВНИТИП, ВНИИКП и др. разработан новый межгосударственный стандарт на полнорационные комбикорма (ГОСТ 18221-99).

В августе 2001 г. научно-технический Совет Минсельхоза России утвердил «Нормы технологического проектирования птицеводческих предприятий» (разработчики: НИПИ агропромышленного комплекса, ВНИТИП, ВНИИ ветеринарной санитарии и экологии, МНТЦ «Племптица»).

Важным организационным событием этого периода развития отрасли стало создание 15 мая 2001 г. Российского птицеводческого союза, учредителями которого явились более 20 крупнейших предприятий и организаций России в лице их руководителей: МНТЦ «Племптица», ВНИТИП, ВНИИПП, ВНИВИП, Сибирский НИИП, племзаводы «Смена», «Конкурсный», «Русь», «Птичное» и др. (директора В.И. Фисинин, В.В. Гущин, Р.Н. Коровин, В.М. Давыдов, Л.И. Тучемский, Е.С. Елизаров, В.В. Слепухин, Ю.В. Косинцев и др.), СХО «Белореченское» (генеральный директор Г.С. Франтенко); ОАО «Россельхозбанк» (председатель правления Ю.В. Трушин); ЗАО «Птицефабрика Боровская» (генеральный директор А.А. Созонов); Птицефабрика «Свердловская» (директор Г.В. Кочнев); АО «Холдинговая компания Элинар» (генеральный директор И.Е. Куимов); ЗАО «Марийское» (генеральный директор А.А. Пушкарев); ОАО «Федеральная корпорация «Росхлебопродукт» (президент Л.С. Чешинский); РАО «Росагробиопром» (генеральный директор П.П. Рахманин); СПК «Птицефабрика «Челябинская» (председатель В.Ф. Мурашов); ППЗ «Новосибирский» (директор И.А. Гоцелюк); ОАО «Племптица-Можайское» (генеральный директор Н.Н. Шабетов); ЗАО «Птицефабрика «Калужская» (генеральный директор В.Д. Евтишенков); ОАО «Ивановский бройлер» (генеральный директор А.П. Вяткин); ППЗ «Свердловский» (директор Г.П. Грачева); Ассоциация «Средуралптицепром» (исполнительный директор А.П. Полумордвинов); Ассоциация «Курганптицепром» (генеральный директор Г.М. Малофеев); Всероссийский научноисследовательский институт защиты животных (ди- ректор А.А. Гусев).

В январе 2002 г. в Министерстве сельского хозяйства РФ Росптицесоюз провел первое годичное собрание, в котором приняли участие более 450 представителей птицепредприятий, научных учреждений и ВУЗов.

Важную роль в этот период играла регулярная переподготовка кадров. ВНИТИП совместно с ВНИИПП и Росптицесоюзом проводили недельные семинары по повышению квалификации руководителей и специалистов птицеводческих предприятий всех форм собственности. Семинары тематические, соответствующие специализации слушателей: экономика, инкубация, селекция, кормление, технология производства яиц и мяса птицы, переработка продукции. В 2001 г. во ВНИТИП курсы переподготовки кадров прошел 401 специалист из 54 регионов Российской Федерации. На эти семинары своих руководителей и специалистов направляли Беларусь, Казахстан, Украина, Узбекистан. В 2002 г. было проведено 11 семинаров, на которых прошли обучение более 850 специалистов из 63 субъектов Российской Федерации и СНГ.

По инициативе МСХ РФ, РАСХН, ВНИТИП, Российского отделения ВНАП на базе Международной промышленной академии в октябре 2000 г. была проведена первая Международная конференциявыставка «Птицеводство-2000». 28-31 января 2002 г. там же была проведена II Международная конференция «Птицеводство - мировой и отечественный опыт» (Poultry-2002). В сборниках материалов этих конференций, в частности, опубликованы работы ученых ВНИТИП: И.А. Егоров, Я.С. Ройтер, А.В. Езерская, А.Н. Шевяков, В.И. Филоненко, К.В. Злочевская, Е.С. Устинова, Т.Н. Ленкова, Т.П. Русецкая, Т.Г. Айдинян, Т.Т. Папазян, Е.Н. Андрианова, В.Г. Шоль, А.Д. Давтян, А.П. Коноплева, Л.Ф. Дядичкина, Н.С. Позднякова, Р.В. Данилов, А.В. Егорова, И.П. Жаркова, А.Ш. Кавтарашвили, Л.М. Ройтер, Л.Л. Горшков, Р.И. Варакина, Н.С. Фузеева и др.

В этот период учеными ВНИТИП был опубликован ряд книг и брошюр, которые также обеспечивали сопровождение развития отрасли. Назовем некоторые из них: В.П. Лысенко «Переработка отходов птицеводства» (1998); А.Д. Давтян «Воспроизводство и искусственное осеменение сельскохозяйственной птицы» (1999); Ш.А. Имангулов, А.Ш. Кавтарашвили «Улучшение окраски скорлупы, желтка яиц и тушки птицы» (1999), «Профилактика и снижение ущерба от ухудшения оперения у птицы, рас- 
клева пера и каннибализма» (1999), А.П. Коноплева, Р.Р. Гадиев «Приусадебное птицеводство» (1999), Н.С. Ковацкий, П.Н. Девятов «Разведение гусей» (1999), Т.М. Околелова и др. «Корма и биологически активные добавки для птицы» (1999), В.И. Фисинин, Ш.А. Имангулов, А.Ш. Кавтарашвили «Повышение эффективности яичного птицеводства» (1999); А.В. Егорова, Е.С. Елизаров, Л.В. Шахнова «Оценка однородности стада мясных кур» (2000), «Племенная работа с мясными курами» (2000), А.П. Коноплева, Ф.П. Савицкий «Разведение кур» (2000), Н.С. Ковацкий «Технология разведения уток» (2000), Т.М. Околелова, А.В. Кулаков, С.А. Молоскин «Витаминно-минеральное питание сельскохозяйственной птицы» (2000), Ш.А. Имангулов, Т.Т. Папазян, А.Ш. Кавтарашвили «Мочекислый диатез. Подагра. Мочекаменная болезнь птицы» (2001), Т.М. Околелова и др. «Корма и ферменты» (2001), Е.С. Елизаров, Л.В. Шахнова, В.А. Манукян «Рост органов и тканей у мясных кур» (2002); Ш.А. Имангулов, Т.Т. Папазян, А.Ш. Кавтарашвили «Клиническая диетология. Снижение ущерба от нарушений метаболизма в опорно-двигательной системе у птицы» (2002); 3.И. Кочетова, Л.С. Белякова «Разведение и содержание перепелов» (2002); В.П. Лысенко «Перспективные технологии и оборудование для реконструкции и технологического перевооружения в птицеводстве» (2002).

Огромную организационную работу по сохранению и функционированию Загорского экспериментального племенного хозяйства ВНИТИП в этот временной период вели директор, доктор сельскохозяйственных наук, профессор В.Г. Шоль и его заместитель по производству и директор ООО «Генофонд» профессор В.И. Филоненко.

На данном этане развития отрасли важную информационную работу осуществляли журналы: «Птицеводство», «Птица и ее переработка», «Комбикорма», «Животноводство России», «Зоотехния», «Ветеринария» и др.

Следующий этап - 2003-2020 гг. - динамичное развитие отрасли. Это время ознаменовано принятием ряда федеральных законов и постановлений Правительства РФ, направленных на повышение экономической эффективности работы сельхозпредприятий. Среди них осуществление финансового оздоровления сельхозпредприятий, субсидирование 2/3 учетной ставки Центробанка России за счет средств федерального бюджета по краткосрочным и долгосрочным кредитам, переход на уплату еди- ного сельскохозяйственного налога.

Важным решением по ускорению темпов прироста отечественного производства мяса птицы явилось принятие и реализация Постановления Правительства Российской Федерации от 23 января 2003 г. №48 «O мерах по защите российского птицеводства».

Все это позволило обеспечить внедрение современных ресурсосберегающих технологий, которые сыграли основную роль в устойчивом наращивании производства птицеводческой продукции. Во многом ускорению темпов роста способствовало принятие коллегией Минсельхоза России 11 мая 2004 г. «Отраслевой целевой программы развития птицеводства в Российской Федерации в 2005-2007 гг. и на период до 2010 г.», над подготовкой которой работал аппарат Росптицесоюза в тесном творческом содружестве с учеными ВНИТИП, ВНИИПП, ВНИВИП, Межрегионального НТЦ «Племптица» и др.

17 декабря 2004 г. на Рефтинской птицефабрике Свердловской области состоялось расширенное заседание коллегии Минсельхоза России с повесткой «О повышении эффективности использования современных технологий ведения птицеводства и их роль в реализации отраслевой целевой программы развития птицеводства в Российской Федерации в 2005-2007 гг. и на период до 2010 г.».

С основным докладом «О повышении эффективности использования современных технологий в птицеводстве» выступил президент Росптицесоюза, директор ВНИТИП В.И. Фисинин.

В числе внедренных разработок отдела технологии производства яиц и мяса птицы ВНИТИП в этот период - технологии выращивания молодняка и содержания родительского стада яичных кур в отечественных клеточных батареях, энергосберегающие световые режимы для птицы различных видов, технологические приемы повышения качества мяса птицы и пищевых яиц в промышленных условиях; технологии производства мяса бройлеров, индеек, уток и продукции гусеводства (мяса гусей, жирной печени и пухо-перового сырья); исходные требования к создаваемому оборудованию для птицеводства; государственные стандарты на птицу для убоя; комплексная технология переработки помета и очистки сточных вод и др.

В 2005 г. началась разработка национальных стандартов.

В эти годы учеными ВНИТИП и координируемых 
НИУ и ВУЗов усовершенствована и успешно реализована система нормированного кормления птицы по обменной энергии, комплексу питательных и биологически активных веществ, предусматривающая основную цель - сокращение затрат кормов на производство продукции.

Были проведены фундаментальные исследования, позволившие разработать и освоить в масштабах отрасли параметры энергетического, протеинового, аминокислотного, жирнокислотного, витаминного и минерального питания с максимальным использованием в рецептуре комбикормов нетрадиционных компонентов и новых кормовых фрорм биологически активных и минеральных веществ отечественного производства.

В связи с изменением экономической ситуации в стране были разработаны и освоены в производстве более дешевые рецепты комбикормов с минимальным содержанием животного белка и применением мультиэнзимных комплексов с учетом содержания некрахмалистых полисахаридов. Шагом вперед в протеиновом и аминокислотном питании явилось то, что была определена потребность птицы в 12 незаменимых аминокислотах с учетом их доступности, изучено их содержание в кормовых средствах. Это позволило снизить содержание сырого протеина в рационах для птицы на 0,5-2,0\%, удешевить комбикорма на 7-10\%, уменьшить загрязнение почвы азотом.

Определены параметры питательности и нормы включения в комбикорма для птицы нетрадиционных кормовых средств. Это позволило существенно расширить ассортимент кормов и сократить расход зерна, применяемого в питании человека. Кормовая база птицеводства была расширена путем использования рапса, люпина, сорго, глютена, конских бобов, амаранта, вики, пайзы, чумизы, продуктов микробиологического синтеза, сухой послеспиртовой барды, травяной муки из разных видов растений, новых сортов просяных культур.

Изучена кормовая ценность и определена возможность использования муки из полножирных семян подсолнечника и бобов сои в кормлении птицы. Такие корма являются источником энергии (до 400 ккал в 100 г), полноценного белка, незаменимых жирных кислот и токоферолов.

Совместно с ВНИИКП (г. Воронеж) ВНИТИП разработаны таблицы питательности кормовых средств, значительно расширен их состав (более 230). Таблицы утверждены Минсельхозом России и РАСХН как единые для комбикормовых заводов и птицехозяйств, разработаны рекомендации для расчета рецептов комбикормовой продукции.

Испытаны и внедрены в производство мультиэнзимные композиции отечественного производства МЭК-СХ-1, МЭК-СХ-2, МЭК-СХ-3, Целловиридин Г20х и ряд других, что позволило увеличить нормы ввода в кормосмеси для птицы таких труднопереваримых компонентов, как рожь, подсолнечные жмыхи и шроты. Апробированы также пробиотики Целлобактерин и Бифидум СХЖ и доказана эффективность их применения в составе комбикормов. Эти работы особенно актуальны в связи с постепенным отказом от использования кормовых антибиотиков.

Следует отметить и тот приятный факт, что в 20032004 гг. ученым и специалистам, работающим в области научного обеспечения промышленного птицеводства, присуждены Премии Правительства.

Так, в 2003 г. присуждены Премии Правительства Российской Федерации в области науки и техники: «За разработку многокомпонентных ферментных препаратов нового поколения для отраслей агропромышленного комплекса», в числе лауреатов Премии - ученый секретарь ВНИТИПТ.Н. Ленкова; «За разработку и усовершенствование ресурсосберегающих и экологически безопасных технологий производства яиц и мяса сельскохозяйственной птицы» (И.И. Кочиш, Р.Х. Кармолиев, В.А. Лукичева, М.С. Найденский, В.В. Нестеров - МГАВМиБ им. К.И. Скрябина, М.А. Асриян, А.Ш. Кавтарашвили, В.С. Лукашенко - ВНИТИП, В.М. Давыдов - Сибирский НИИптицеводства) и др.

Лауреатами Государственной премии РФ в области науки и техники 2004 г. «За научную разработку и освоение отечественных кормовых ресурсов в птицеводстве» стали: И.А. Егоров, Т.М. Околелова, Г.В. Игнатова, Ш.А. Имангулов (ВНИТИП), В.К. Менькин (МСХА им. К.А.Тимирязева), Ю.В. Косинцев (ГППЗ «Птичное»), Г.В. Кочнев (Свердловская птицефабрика).

Несомненно, важнейшим событием для динамичного развития отрасли явился приоритетный национальный проект «Развитие АПК» (2006-2007).

В 2003-2010 гг. прошли первые международные форумы и выставки по птицеводству в Москве - «VIV Россия», «Мясная промышленность. Куриный король», в работе которых активное участие приняли ученые ВНИТИП и ВНИИПП.

В феврале 2009 г. во ВНИТИП состоялся Международный форум по бройлерному птицеводству, в 
котором приняли участие 375 специалистов и ученых 214 компаний и предприятий из 12 стран. На пленарных заседаниях и круглых столах были рассмотрены стратегические аспекты развития мирового и отечественного птицеводства, актуальные проблемы генетики и селекции, кормления птицы, технологии производства и переработки продукции, ветеринарной безопасности, экономики и маркетинга. Дискуссионные обсуждения проблем, несомненно, обогатили участников форума новыми знаниями.

Состоялся ряд Международных конференций по птицеводству, а также были изданы сборники материалов III, V, VII Международных ветеринарных конгрессов по птицеводству (2007, 2009, 2011 ), в которых опубликованы работы ученых ВНИТИП: И.А. Егорова, А.Н. Шевякова, Т.М. Околеловой, В.С. Савченко и др. На данном временном периоде развития птицеводства научное обеспечение отрасли осуществляли научные учреждения РАCХН по Программам фундаментальных и приоритетных прикладных исследований по научному обеспечению развития АПК РФ на 20012005 и 2006-2010 гг. В соответствии с Программой, исследова-

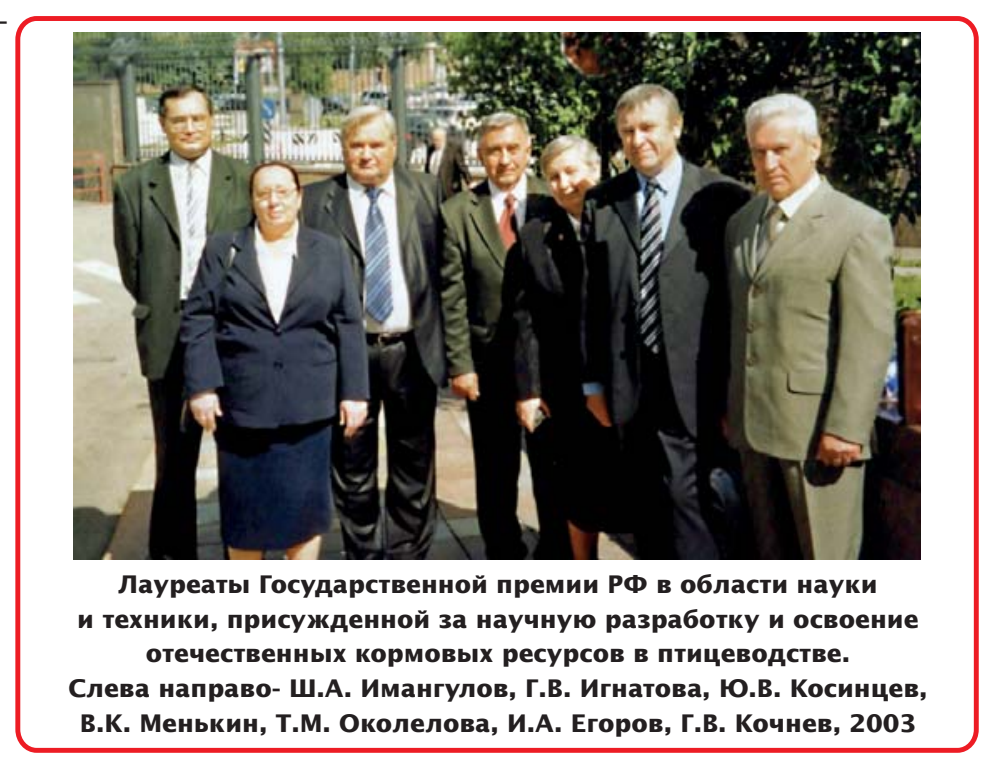

и мяса птицы для максимального использования генетического потенциала современных кроссов» (ВНИТИП, ВНИИПП, СибНИИП и др.); 07.04 «Разработать высокоэффективные технологии и создать оборудование для производства конкурентоспособных продуктов из мяса птицы» (ВНИИПП, ВНИИжиров).

По научной Программе ветеринарных исследований выполнялось задание 08.07 «Разработать новые высокоэффективные средства и оптимальные способы их применения для диагностики, профилактики и борьбы с инфекционными и паразитарными болезнями, наносящими наибольший ущерб промышленному птицеводству» (ВНИВИП, ВИЭВ, ВНИИВСГиЭ, ВНИТИП, ВНИИПП и др.).

В координационных программах ВНИТИП и ВНИВИП определенную долю исследований вели ния по птицеводству в 2006-2010 гг. велись по заданиям 07.01 «Разработать программу повышения генетического потенциала сельскохозяйственной птицы, использовав биотехнологические и генетические методы, обеспечивающие эффективность производства птицеводческой продукции» (ВНИТИП, ВНИИГРЖ, Сибирский НИИП, экспериментальные хозяйства и племзаводы); 07.02 «Разработать нормы кормления сельскохозяйственной птицы современных высокопродуктивных кроссов по доступным для усвоения питательным веществам на основе углубленного изучения кормовых средств, энергетического, жирнокислотного, аминокислотного и минерального обмена у яичных и мясных кур» (ВНИТИП, СибНИИП, ВНИИ кормов, МНТЦ «Племптица»); 07.03 «Разработать технологии производства, переработки и повышения качества яиц жения защищены 76 авторскими свиде-тельствами и 83 патентами.

Учеными-селекционерами ВНИТИП в содружестве со специалистами племзаводов за данный период разработан целый ряд методических рекомендаций, наставлений, инструкций, методик и национальных стандартов: рекомендации по работе с аутосексным кроссом кур белый леггорн «Бугульма»; рекомендации по разведению и использованию башкирской цветной породы уток; рекомендации по работе с аутосексным четырехлинейным кроссом «Родонит-2»; методические рекомендации по разведению гусей; рекомендации по племенной работе в птицеводстве; рекомендации по искусственному осеменению сельскохозяйственной птицы; Национальный стандарт Российской Федерации ГОСТ P 53397. 
По заданию 07.02 учеными ВНИТИП была усовершенствована и успешно реализована система нормированного кормления по обменной энергии, комплексу питательных и биологически активных веществ, обеспечивающая основную цель экономики отрасли - сокращение расхода кормов на продукцию.

Были проведены фундаментальные исследования, позволившие разработать и освоить в масштабах отрасли параметры энергетического, протеинового, аминокислотного, жирнокислотного, витаминного и минерального питания с максимальным использованием в рецептуре комбикормов нетрадиционных компонентов и новых кормовых форм биологически активных и минеральных веществ отечественного производства.

На основании проведенных исследований были разработаны методические рекомендации: «Использование комплексных ферментных препаратов (мультиэнзимных композиций) при производстве комбикормов для сельскохозяйственных животных и птицы» (2004); «Ферменты в кормлении птицы» (2005); «Органические кислоты и подкислители в кормах для птицы» (2006); «Использование пробиотиков, пребиотиков и симбиотиков в птицеводстве» (2008); «Биологически активные и кормовые добавки в птицеводстве» (2009); «Органические формы микроэлементов в кормлении сельскохозяйственной птицы» (2010).

Изучена кормовая ценность ряда новых и нетрадиционных кормовых средств (вики, чумизы, биокорма, сойкомила, отечественного соевого молока, глютеновой муки, голозерного овса, тонкопленчатого проса, послеспиртовой барды из пшеницы, ячменя и сорго). Результаты исследований вошли в методические рекомендации.

Разработано более 200 рецептов комбикормов для птицы современных кроссов. Предложены производству способы снижения негативного влияния микотоксинов на организм птицы, которые запатентованы.

В рамках задания 07.03 ВНИТИП разработаны технологии и технологические приемы содержания бройлеров, родительского стада мясных кур, яичных кур, индеек, перепелов. Выпущены методические рекомендации «Технология раздельного кормления петухов и кур мясных кроссов» (2006).

Созданы технологические приемы выращивания бройлеров на обогреваемых полах и с помощью автономных обогревателей.

Определены технологические параметры выра- щивания бройлеров с дифференцированной плотностью посадки в стартовый период при поточной технологии, позволяющей на 20-25\% повысить коэффициент использования птицеводческих помещений.

Экспериментально обоснованы эффективные технологические приемы производства продукции индейководства, которые вошли в методические рекомендации «Технология производства мяса индеек» (2005). Опубликованы рекомендации: «Ресурсосберегающая технология производства яиц и мяса перепелов» (2005), «Технология содержания перепелов в фермерских хозяйствах» (2006).

Разработаны рациональные режимы прерывистого освещения племенных кур и петухов яичных кроссов, параметры освещенности петухов родительского стада, технология выращивания ремонтного молодняка яичных кур.

Подготовлены исходные требования к комплекту оборудования для содержания родительского стада яичных кур в клеточных батареях с раздельным кормлением кур и петухов, рекомендации «Прогрессивные ресурсосберегающие технологии производства яиц» (2009).

Научно обоснована концепция переработки отходов птицефабрик в новые виды побочной продукции, на основе которой изданы рекомендации «Подготовка помета на птицефабриках для промышленной переработки в удобрение» (2007); «Очистка и обеззараживание сточных вод птицефабрик» (2008). Федеральное агентство по техническому регулированию и метрологии утвердило в 2009 г. национальный стандарт РФ ГОСТ Р 53765-2009 «Помет птицы. Сырье для производства органических удобрений. Технические условия».

Разработаны национальные стандарты: ГОСТ P52121-2003 «Яйца куриные пищевые»; «яйца пищевые (индюшиные, цесариные, перепелиные, страусиные). Технические условия» (2009); «Птица сельскохозяйственная для убоя. Технические условия» (2007).

Изучены отклонения в развитии эмбрионов и выведенного молодняка при различных нарушениях технологических процессов инкубации яиц, качество яиц высокопродуктивных кроссов яичных и мясных кур, гусей, уток, индеек, предложены новые технологические приемы инкубации яиц водоплавающей птицы. Материалы исследований были использованы при разработке трех ОСТов на яйца и суточный молодняк, опубликованы методические рекомендации «Инкубация яиц сельскохо- 
зяйственной птицы» (2005).

В период 2003-2010 гг. сотрудниками отдела экономики рыночных отношений ВНИТИП подготовлены и опубликованы следующие научные разработки: «Методические рекомендации по оценке эффективности инвестиционных проектов в птицеводстве» (2003); «Типовые должностные инструкции управленческих работников птицеводческих предприятий (всех форм собственности)» (2005); «Методические рекомендации по реализации резервов эффективности в производственной и маркетинговой деятельности предприятий АПК» (2006); «Методические рекомендации по оценке финансового состояния птицеводческого предприятия» (2006); «Методика построения сбалансированной системы показателей в маркетинговой деятельности птицеводческого предприятия» (2010); «Методика оценки результативности функционирования птицеводческих предприятий» (2010); «Методика оценки селекционного достижения в птицеводстве» (2010) и др. 2010 гг. на разработки фундаментального и приоритетного прикладного характера учеными ВНИТИП было получено 38 патентов РФ на изобретения. По исследованиям в области кормления сельскохозяйственной птицы и микотоксикологии получены следующие патенты: «Корм

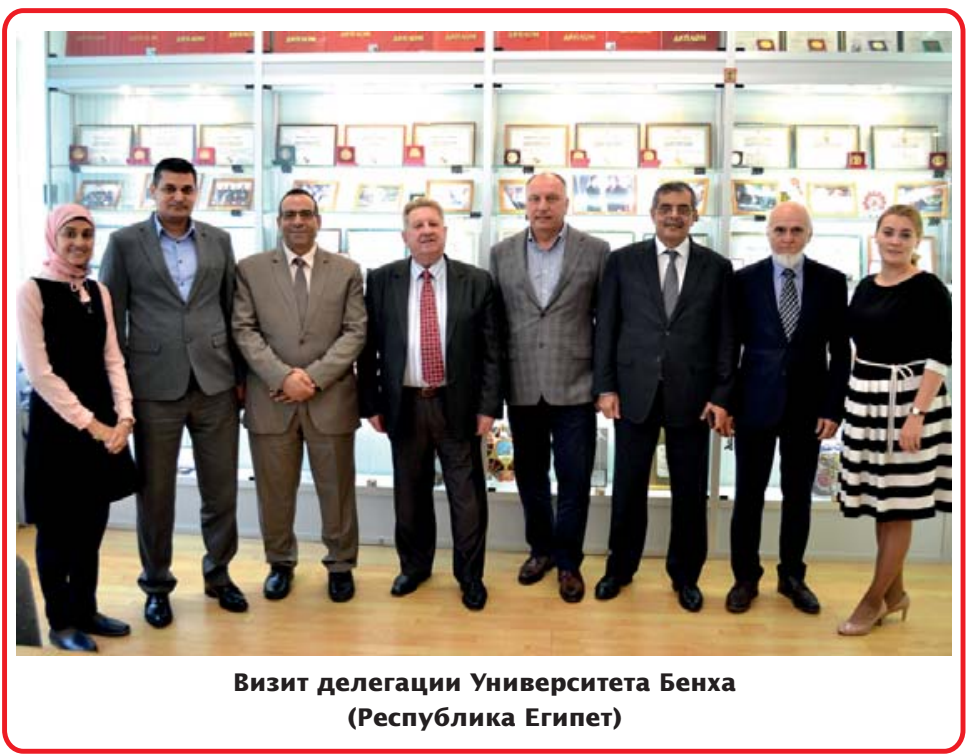
ции» (2010).
За период 2003-

молодняка сельскохозяйственной птицы» (2004); «Способ отбора племенных мясных петухов» (2004); «Способ отбора мясных кур селекционного стада» (2004); «Способ сравнительной оценки силы реакции гистонесовместимости у птиц» (2005); «Способ содержания племенных петухов» (2006); «Способ отбора петухов племенного стада при групповом содержании» (2007); «Способ отбора мясных кур селекционного стада по яйценоскости» (2008); «Способ определения фенотипически невыраженных форм сельскохозяйственной птицы» (2009); «Способ индукции иммунологической толерантности у птиц» (2009); «Способ повышения функциональной активности половых желез у самцов сельскохозяйственных птиц» (2009); «Способ разделения аутосексных мясных цыплят по полу» (2009); «Способ комплектования родительского стада мясных кур» (2010); «Способ отбора цесарок при селек-

для сельскохозяйственной птицы» (2003); «Цветовая шкала для определения пигментированности кожи тушек мясной и яичной птицы» (2003), «Корм для молодняка птицы предстартового периода» (2003); «Корм для цыплят-бройлеров» (2005); «Способ кормления цыплят-бройлеров» (2006); «Способ профилактики микотоксикозов у сельскохозяйственной птицы» (2008); «Способ стабилизации комбикормов» (2008), «Способ профилактики микотоксикозов у сельскохозяйственных животных и птицы» (2010); «Кормовая добавка для профилактики микотоксикозов у сельскохозяйственной птицы» (2010) и др.

По селекции сельскохозяйственной птицы получены патенты на следующие изобретения: «Синтетическая среда для разбавления спермы птиц» (2003); «Способ повышения напряженности иммунитета
По технологии выращивания и содержания птицы были получены патенты: «Способ содержания перепелов» (2005); «Способ из соломы при выращивании цыплятбройлеров» (2008); «Клеточная батарея для содержания сельскохозяйственной птицы» (2009); «Способ повышения инкубационных качеств перепелиных яиц» (2009); «Клеточная батарея для выращивания бройлеров» (2009); «Клетка для содержания птицы» (2009).

С 2003 nо 2010 гг. был опубликован целый ряд книг по различным направлениям развития птицеводства, соавторами которых были ученые ВНИТИП: Е.С. Елизаров, А.В. Егорова, Л.В. Шахнова «Племенная работа с мясными курами» (2003); И.П. Жаркова «Разведение уток» (2004); «Разведение гусей» (2004); Я.С. Ройтер, А.Ф. Лукьянов, В.В. Герасименко «Научные и практические аспекты разведения гусей» (2004); Е.С. Устинова «Разведение кур» (2004); Н.А. Попков, В.И. Фисинин, И.А. Егоров и др. «Корма и биологически активные вещества» (2005); Г.А. Тардатьян «Терминологический словарьсправочник по птицеводству» (2006); В.И. Фисинин, С.Ф. Суханова, А.Г. Махалов «Гуси Урала»; (2008); подготовки подстилки 
Ю.А. Пономаренко, В.И. Фисинин, И.А. Егоров, В.С. Пономаренко «Корма, кормовые добавки, биологически активные вещества для сельскохозяйственной птицы» (2009); Т.А. Столляр, В.С. Лукашенко «Технология производства мяса бройлеров» (2009); В.И. Фисинин «Птицеводство России - стратегия инновационного развития» (2009); Н.Н. Корнева, В.П. Лысенко «Экологические и экономические перспективы развития промышленного птицеводства» (2009); А.В. Иванов, В.И. Фисинин, М.Я. Тремасов, К.Х. Папуниди «Микотоксикозы (биологические и ветеринарные аспекты)» (2010); 3.И. Кочетова, Л.С. Белякова «Перепеловодство - выращивание и содержание» (2010); Л.И. Подобед, Т.М. Околелова «Диетопрофилактика кормовых нарушений в интенсивном птицеводстве» (2010).

Системный подход к развитию отрасли, новаторству, обусловливающему ее конкурентоспособность, возможен при наличии интеллектуального кадрового потенциала. Несомненно, что наиболее эффрективные вложения инвестиций - это вложения в человека. Именно поэтому Росптицесоюз, ВНИТИП, ВНИИПП, ВНИВИП, СибНИИП, СевероКавказская ЗОСП и координируемые научные учреждения продолжили в этот период проведение семинаров - курсов повышения квалификации специалистов различного направления. Так, в 2010 г. только на базе ВНИТИП было проведено 18 семинаров, на которых обучение прошли 720 специалистов из 68 субъектов РФ, с вручением свидетельств о повышении квалификации.

Во ВНИТИП для участников семинаров организованы специальные, технологические платформы кабинеты, где представлены функционирующие фрагменты клеточного и напольного оборудования, инкубаторы, вентиляционные и осветительные системы и др. (ПО «ТЕХНА», ООО «Резерв», компания «СТИМУЛ ИНК», ОАО «ГолицЫнский завод средств автоматизации», зарубежные фирмы). Каждый участник курсов повышения квалификации может получить здесь интересующие его рекламные материалы предприятий-изготовителей оборудования, посмотреть телевизионную версию работы технических средств на птицефабриках, получить квалифицированную консультацию.

Учитывая потенциал отечественного птицеводства и его вклад в решение продовольственной безопасности страны, Председатель Правительства РФ В.В. Путин 14 января 2010 г. провел в Ленинградской области совещание по дальнейшему интенсивному развитию птицеводства. В работе совещания принимали участие 15 человек: первый заместитель председателя правительства В.А. Зубков, представитель президента по Северо-Западному федеральному округу И.И. Клебанов, министр сельского хозяйства России Е.Б. Скрынник, губернатор Ленинградской области В.П. Сердюков, зам. губернатора С.В. Яхнюк, заместитель министра экономического развития А.Н. Клепач, директор Департамента АПК правительства И.М. Руденя, президент Росптицесоюза В.И. Фисинин, генеральный директор Росптицесоюза Г.А. Бобылева, директор Леноблптицепрома Ю.В. Трусов, директора предприятий: «Роскар» Ленинградской области В.П. Горячев; «Рефтинская» Н.В. Топорков; «Равис-птицефабрика «Сосновская» П.А. Подгорнов, «Моссельпром» О.Е. Чуприков. Более 2 часов проходило конструктивное доброжелательное обсуждение проблем развития отечественного птицеводства. Председатель Правительства внимательно выслушал всех участников совещания и детально рассмотрел предложения руководителей предприятий по таможеннотарифной политике, кредитной политике банков, о сложившейся системе железнодорожных перевозок и тарифах на электроэнергию и газ, о зерновом рынке, сложившемся порядке распределения квот на импорт, необходимости создания отечественных селекционно-генетических центров и о производстве техники и оборудования на российских заводах. В заключение обсуждения В.В. Путин четко сформулировал задачу, стоящую перед отраслью: в течение ближайших трех лет уйти от импорта птицепродуктов и поставлять жителям нашей страны свежую высококачественную диетическую продукцию - яйца и мясо птицы - по доступной цене.

Председатель Правительства РФ распоряжением № В-П11-561 от 3 февраля 2010 г. дал поручение Министерству сельского хозяйства России с участием отраслевых союзов и научно-исследовательских институтов разработать программу «Развитие птицеводства в Российской Федерации на 2010-2012 гг. и на период до 2018-2020 гг.». Над составлением Программы под эгидой Минсельхоза России работали: Росптицесоюз, ВНИТИП, ВНИИПП, ВНИВИП.

Основные индикаторы программы предусматривали достижения к 2020 г. следующих показателей: производство мяса птицы в убойной массе - 4,5 млн. т, пищевых яиц - 45 млрд. шт.

Научное обеспечение Программы развития отрасли осуществлялось научными учреждениями, в соответствии с планом фундаментальных и прикладных исследований Российской академии наук. 
2015 год для птицеводов страны был ознаменован славным юбилеем - 50-летием отечественного промышленного птицеводства.

В ознаменование полувекового юбилея 21 мая 2015 г. Росптицесоюз провел совещание руководителей в Москве в центре «Крокус-Сити». Среди приглашенных были ветераны отрасли, руководители и специалисты предприятий и отраслевых научных организаций - ВНИТИП, ВНИИПП, ВНИВИП, СибНИИП. Ветеранам и передовикам отрасли были вручены награды.

Звания «Почетный работник агропромышленного комплекса России» были удостоены 26 руководителей и специалистов из 24 регионов. Почетной грамотой Министерства сельского хозяйства РФ наградили 23 руководителя из 16 регионов. Благодарность Министерства сельского хозяйства РФ объявили 75 руководителям и специалистам из 33 регионов. Всего были отмечены 133 руководителя и специалиста из 63 субъектов Российской Федерации.

Среди награжденных были ученые ВНИТИП и ЭПХ ВНИТИП: К.В. Злочевская, Л.В. Шахнова, Я.С. Ройтер, И.А. Егоров, Т.Н. Ленкова, В.А. Манукян, И.П. Салеева, В.С. Лукашенко, А.Ш. Кавтарашвили, А.В. Егорова, Т.М. Околелова, Л.М. Рой-

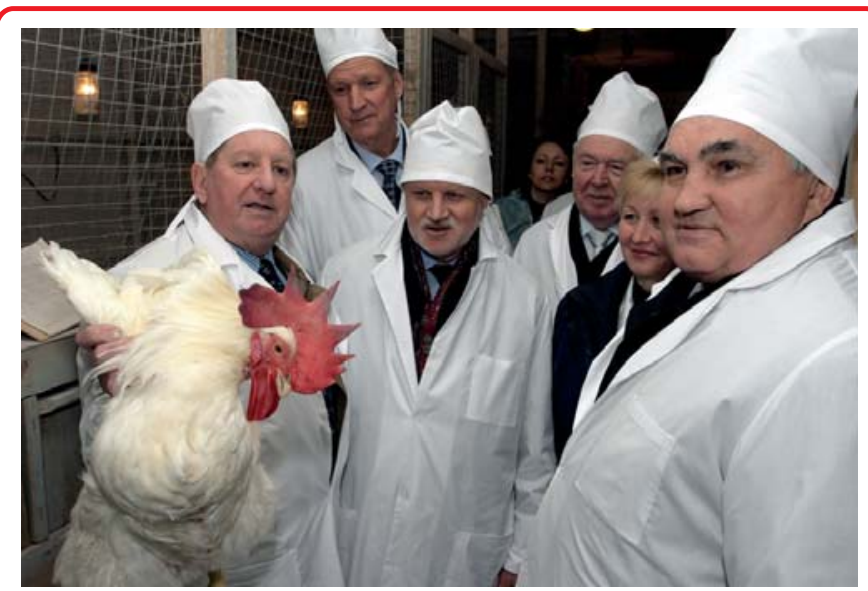

В племптицзаводе «Смена»Россельхозакадемии. Слева направо -

В.И. Фисинин, Г.А. Горбунов, С.М. Миронов,

Г.А. Романенко, Ж.В. Емануйлова, Л.И. Тучемский, 2008 ференции - более 200. Это наглядно демонстрирует динамичное развитие птицеводческой науки и ее роль в эффективной работе отрасли. В работе конференции приняли участие более 350 ученых и специалистов, в том числе 29 зарубежных ученых из 15 стран.

Приказом ФАНО Российской Федерации от 30 июня 2015 г. №340 был создан Федеральный научный центр (ФНЦ) «ВНИТИП» РАН, в который вошли 3 института - ВНИТИП, ВНИИПП, ВНИВИП, в мае 2017 г. - СгЦ Северо-Кавказская ЗОСП и СГЦ Загорское ЭПХ ВНИТИП, в 2020 г. - СГЦ ГППЗ «Смена».

ФНЦ «ВНИТИП» РАН разработана комплексная целевая программа «Научное обеспечение создания племенного фонда, производства конкурентоспособной сельскохозяйственной продукции птицеводства с использованием российских кормов, кор- тер, Т.А. Столляр, Г.В. Красноярцев, А.Н. Шевяков, Д.В. Аншаков, В.Г. Шоль.

В мае 2015 г. во ВНИТИП состоялась XVIII Международная конференция Российского отделения Всемирной научной ассоциации по птицеводству (ВНАП) «Инновационное обеспечение яичного и мясного птицеводства России». Участников конференции приветствовали генеральный секретарь ВНАП Рул Мулдер (Нидерланды), президент Турецкого отделения ВНАП профессор Рувейда Акбай, профессор Рудольф Прайзингер (Германия), Питер Сурай (Шотландия).

В сборнике материалов конференции представлены статьи авторов из 29 НИИ, 21 университета, 10 академий, 33 фирм и 16 птицеводческих предприятий из 19 стран. Следует отметить, что в 1968 г. в сборнике национального отделения ВНАП было всего 12 тезисов докладов, а XVIII Международной кон- мовых добавок и лекарственных средств для животных, а также по созданию технологий производства (выращивания), хранения и переработки птицы на 20162025 гг.».

Программа включает четыре параллельно идущих и взаимодействующих комплекса научноисследовательских работ с различными горизонтами планирования.

В последнее десятилетие отмечено значительное сокращение удельного веса отечественных пород и кроссов сельскохозяйственной птицы в производ-стве продукции, что представляет серьезную угрозу продовольственной безопасности России. Это в полной мере относится к отечественному растениеводству и животноводству. Решение данной проблемы поставлено на государственный общенациональный уровень.

Указом Президента РФ №350 от 21 июля 2016 г. «О мерах по реализации государственной научнотехнической политики в интересах развития сельского хозяйства» сформулировано: «Разработать и реализовать комплекс мер, направленных на создание и внедрение до 2026 г. конкурентоспособных отечественных технологий, основанных на новейших достижениях науки и обеспечивающих: a) производство оригинальных и элитных семян сельскохозяйственных растений по направлениям 
отечественного растениеводства и племенной продукции животноводства, имеющим в настоящее время высокую степень зависимости от семян и племенной продукции иностранного производства».

В соответствии с Указом Президента был создан Совет по реализации Федеральной научнотехнической программы (ФНТП) и принято решение: на первом этапе разработать программы по двум направлениям - картофелеводство и птицеводство.

Специалистами СГЦ «Смена» совместно с ФНЦ «ВНИТИП» РАН и другими научными учреждениям разработана Подпрограмма «Создание отечественного конкурентоспособного кросса мясных кур в целях получения бройлеров» в рамках ФНТП развития сельского хозяйства на 2017-2025 гг.

В настоящее время эта фундаментальная работа проводится на базе СГЦ «Смена». В ряде субъектов РФ проведены испытания бройлеров нового кросса (Челябинская, Свердловская области, Ставропольский край, Республика Адыгея и др.).

В начале 2018 г. двум работам в области животноводства и птицеводства были присуждены Премии Правительства РФ 2017 г. в области науки и техники.

За разработку «Комплексная система воспроизводства сельскохозяйственной птицы на основе биологического контроля, инновационных технологий, инкубационного оборудования, обеспечивающая повышение эффеективности птицеводческой отрасли» звания Лауреатов Правительственных премий РФ в области науки и техники присвоено: Л.Ф. Дядичкиной, Ю.С. Голдину, Т.А. Мелехиной, Н.С. Поздняковой, Л.М. Ройтер (ФНЦ «ВНИТИП» РАН), Э.Н. Азизову (АО «Ярославский бройлер»), Д.В. Аншакову (СГЦ «Загорское ЭПХ» ВНИТИП), А.Н. Воронцову (ОАО «ГСКБ» г. Пятигорск), Л.Ю. Костевой (ОАО «Волжанин»), П.П. Царенко (Санкт- ПетербургСКий ГАУ).

За проект «Разработка современных технологий для повышения продуктивности сельскохозяйственных животных, улучшения качества животноводческой продукции, эффективной охраны экосистем с учетом регуляции микробиома» звание Лауреатов Правительственной премии РФ в области науки и техники присвоено: Г.Ю. Лаптеву, В.Н. Большакову, И.Н. Никонову, Л.А. Ильиной, Н.И. Новиковой (ООО «Биотроф»), В.А. Манукяну (ФНЦ «ВНИТИП» РАН), И.И. Кочишу (МГАВМиБ - МВА им. К.И. Скрябина), А.Н. Косилову (ООО «Равис - птицефабрика «Сосновская»).
В мае 2018 г. в ФНЦ «ВНИТИП» РАН состоялась XIX Международная конференция Российского отделения ВНАП «Мировые и российские тренды развития птицеводства: реалии и вызовы будущего». В работе конференции приняли участие 415 ученых и специалистов по птицеводству из 23 стран.

В сборник трудов конференции (775 страниц) вошло 259 статей. Назовем некоторые, где авторами являются ученые ФНЦ «ВНИТИП» РАН: А.М. Долгорукова, В.Ю. Титов «Биохимические факторы, определяющие мясную продуктивность сельскохозяйственных птиц на эмбриональной стадии», Ж.В. Емануйлова, Д.Н. Ефимов, Л.И. Тучемский, А.В. Егорова, О.П. Лесик «Отбор и подбор мясной птицы материнской линии отцовской родительской формы на увеличение племенной продукции», А.П. Коноплева, А.А. Андреева, Т.Н. Трохолис «Новые среды разбавления спермы сельскохозяйственных птиц, созданные во ВНИТИП, способы их хранения и использования», Л.Г. Коршунова, Р.В. Карапетян «Методы молекулярной генетики в селекции сельскохозяйственной птицы», Я.С. Ройтер, Д.В. Аншаков, Т.Н. Дегтярева, О.Н. Дегтярева «Мониторинг сохранения биоразнообразия пород перепелов», В.Г. Вертипрахов, А.А. Грозина «К вопросу о механизме адаптации пищеварения кур к питательной ценности рациона», И.А. Егоров, В.Г. Вертипрахов, А.А. Грозина, Т.Н. Ленкова, В.А. Манукян, Т.А. Егорова «Развитие пищеварительной системы в эмбриональный и постэмбриональный период у мясных цыплят исходных линий и их гибридов», В.А. Гусев, А.Ш. Кавтарашвили, И.П. Салеева, Е.Н. Новоторов, Л.А. Зазыкина, Т.Н. Кузьмина, О. Н. Гусева «Оборудование для содержания кур промышленного стада», И.А. Егоров, В.Г. Вертипрахов, А.А. Грозина, Т.Н. Ленкова, В.А. Манукян, Т.А. Егорова «Пищеварительные ферменты в кишечнике и плазме крови у цыплят-бройлеров при использовании в их рационе биологически активных добавок», Ф.Ф. Алексеев, В.Г. Шоль, Е.А. Овсейчик «Режим прерывистого освещения при выращивании индюшат до 8недельного возраста», Н.Н. Гогина, Л.М. Круглова, Ю.С. Кожаринова, «Мониторинг содержания микотоксинов в кормах Средней полосы Российской Федерации за 2015-2016 гг.», Л.М. Ройтер, С.И. Валдохина, Л.Ю. Костева «Качество продукции как индикатор конкурентоспособности птицеводческого предприятия», В.И. Фисинин, И.П. Салеева, В.С. Лукашенко, В.Г. Волик, Д.Ю. Исмаилова, Е.В. Журавчук, Е.А. Овсейчик «Влияние различных сроков и способов выращивания на продуктивность 
цыплят-бройлеров».

В период динамичного развития отрасли (20102020 гг.) важную роль в информационном обеспечении руководителей и специалистов птицепредприятий сыграли новые издания книг по различным проблемам промышленного птицеводства с обобщением мировых и отечественных достижений науки и практики. Назовем несколько книг по птицеводству, соавторами которых являются ученые ВНИТИП: В.И. Фисинин, И.А. Егоров, И.Ф. Драганов «Кормление сельскохозяйственной птицы (2011); В.И. Фисинин, В.В. Калашников, И.Ф. Драганов, Х.А. Амерханов «Новое в кормлении животных» (2012); В.И. Фисинин, П.Ф. Су-рай, А.И. Кузнецов, В.А. Мифтахутдинов, А.А. Терман «Стрессы и стрессовая чувствительность кур в мясном птицеводстве: диагностика и профилактика»; И.М. Дунин, В.В. Калашников, Я.С. Ройтер, В.А. Багиров, Х.А. Амерханов, Г.И. Шичкин, Г.Ф. Сафина, С.А. Данкверт и др. «Справочник пород и типов сельскохозяйственных животных,

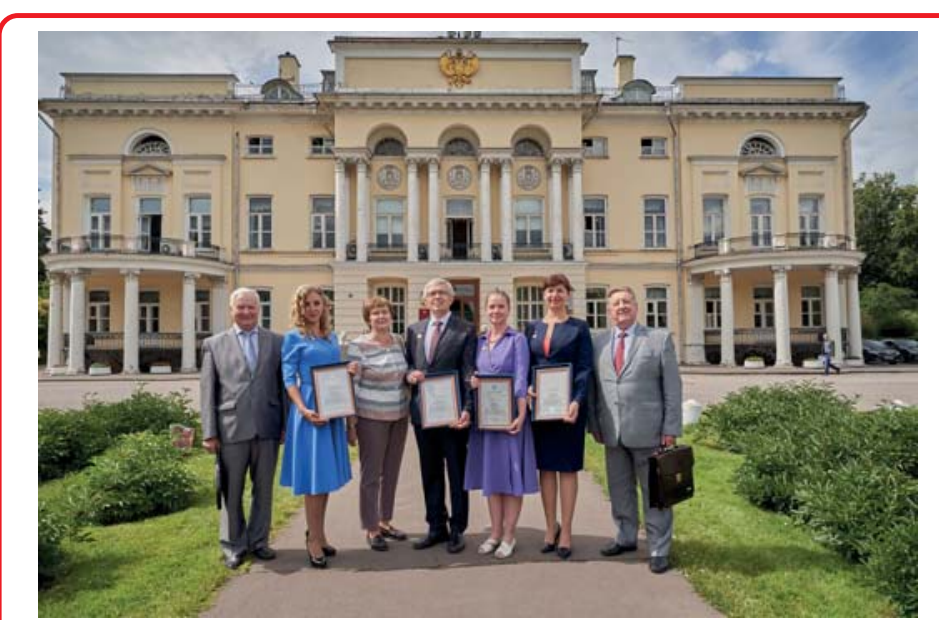

Награждение лауреатов премии Правительства РФ в области науки и техники среди молодых ученых за 2019 год
Индикаторы Программы «Развитие птицеводства в Российской Федерации на 2010-2012 годы и на период до 2018-2020 гг.» были достигнуты досрочно. В 2019 г. производство мяса птицы достигло 5 млн. 8 тыс. тонн, на душу населения - 34,2 кг; производство пищевых яиц - 44,9 млрд. шт., на душу населения - 305 шт. Если в 2000 г. Россия по производству мяса птицы занимала в мировом рейтинге 20-е место, то в настоящее время - 4-е место, а по производству яиц - 7-е.

Последнее десятилетие (2010-2020 гг.) отделы и лаборатории ВНИТИП эффективно работали по заданиям госпрограммы научных исследований по различным направлениям. Чисто тезисно охарактери- разводимых в Россий-

ской Федерации» (2013); Л.Ф. Дя-дичкина и др. «Биологический контроль при инкубации яиц сельскохозяйственной птицы» (2014); В.С. Лукашенко, Л.Ф. Дядичкина, Я.С. Ройтер, Т.Н. Ленкова, Т.А. Егорова, Е.Е. Тяпугин и др. «Адаптивная ресурсосберегающая технология производства яиц» (2016); Я.С. Ройтер, А.В. Егорова, А.П. Коноплева и др. «Селекционно-племенная работа в птицеводстве» (2016); Л.М. Ройтер, А.Г. Акопян, И.В. Веденкина, С.И. Валдохина «Методика оценки результативности системы менеджмента качества на птицеводческих предприятиях» (2016); В.И. Фисинин, Г.Ю. Лаптев, И.А. Егоров, А.А. Грозина, Т.Н. Ленкова, Т.В. Егорова, В.А. Манукян, Т.А. Егорова и др. «Современные представления о микрофлоре кишечника птицы при различных рационах питания: молекулярногенетические подходы» (2017), монографии В.И. Фисинина «История птицеводства российского» (2014 т.І и 2016 т.ІІ), «Мировое и российское птицеводство: реалии и вызовы будущего» (2019). породы и 2 кросса.

Порода «Губернаторские гуси» (патент №6 104 от 13.10.2011) выведены в результате сложного воспроизводительного скрещивания гусей итальянской и местной шадринской породы. Особенностью гусей этой породы является колорсексная окраска пуха суточного и пера подрощенного молодняка (генотип G/GSd/Sd; Sp/spC/cx G/-S/-Sd/-; Sp/SpC/C).

Порода «Уральские серые гуси» (патент №7694 от 11.02.2015). За основу создания породы были взяты местные серые, крупные серые и ландские гуси. В результате многолетней селекционной работы в ООО «ППЗ Благоварский» создана порода гусей с серой окраской оперения, отличающаяся от других пород высокой продуктивностью и жизнеспособностью.

Перепела «Радонежские» (патент № 9996 от 23.01.2019). В результате сложного воспроизводительного скрещивания пород фараон и техасские белые с последующей длительной селекцией (11 
поколений), направленной на повышение продуктивных и воспроизводительных качеств, была выведена данная порода перепелов. За период селекции живая масса перепелов была увеличена на 31\%, конверсия корма на 13,4\%. Живая масса созданной породы в 5-недельном возрасте составляет: перепела - 290 г; перепелки - 315 г, конверсия корма - 2,35 кг/кг прироста живой массы, сохранность молодняка- $97,0 \%$.

Двухлинейный кросс уток «Агидель 34» (патент №6779 от 15.01.2013) и трехлинейный кросс уток «Агидель 345» (патент №6777 от 15.01.2013). Кроссы созданы методом сложного воспроизводительного скрещивания линий кросса «Благоварский» с линиями кросса «Супер М» (фирма Черри-Велли, Великобритания).

Птица получила повсеместное распространение в РФ и близлежащих странах: Казахстан, Узбекистан, Киргизия.

В отделе генетики и селекции также проведены комплексные исследования по созданию новых форм птицы, отличающейся специфическими вкусовыми и пищевыми достоинствами.

В последние годы отделом кормления ВНИТИП получены новые, более точные сведения о потребности птицы в питательных веществах; о доступности для птицы питательных веществ из различных кормовых компонентов; уточнены уравнения регрессии для оценки обменной энергии компонентов комбикормов по фактическим показателям питательности, для оценки аминокислотного состава компонентов по содержанию сырого протеина.

Учеными установлено, что из комбикормов, в состав которых входили животные компоненты, куры усваивали более 83\% общего лизина, а из чисто «растительных» кормосмесей такой же питательности - только 63-76\%, что влияет на состояние иммунной системы птицы.

Естественно, что при нормировании по валовому содержанию питательных веществ птица испытывает дефицит усвояемых веществ, который усугубляется еще и тем, что современные кроссы отличаются повышенным обменом веществ, при котором возрастает вероятность появления вирусных и бактериальных инфекций. Скорость усвоения питательных веществ и энергии из таких комбикормов не соответствует генетически обусловленной интенсивности синтеза белка и липидов яйцемассы, а также прироста живой массы, появляются симптомы «условного» дефицита. Такие симптомы чаще всего прояв- ляются в форме пониженной общей резистентности, анемии, расклева, внезапного снижения интенсивности яйценоскости или прироста живой массы и вынужденного сокращения срока эксплуатации кур.

Поэтому в последние годы возникла острая необходимость не только уточнения норм потребностей сельскохозяйственной птицы и переоценки питательности кормов, но и совершенствования всей системы нормированного кормления. В настоящее время кардинально изменена система оценки кормовых средств по обменной энергии.

В целом эти исследования вылились в рекомендации для производства, в которых представлены калорические коэффициенты пересчета кормов по содержанию в них протеина, жира и БЭВ. Во ВНИТИП проведены физиологические опыты по изучению переваримости молодняком и взрослой птицей основных питательных веществ, и на основании полученных результатов произведен расчет обменной энергии по кормовым средствам для взрослой птицы и молодняка.

Согласно последним данным, к незаменимым жирным кислотам относят только линолевую кислоту, поскольку в организме птицы линоленовая и архидоновая кислоты могут синтезироваться из нее. Однако исследования ученых отдела кормления ВНИТИП показали, что линоленовая и арахидоновая кислоты также являются незаменимыми, как и линолевая, и их необходимо нормировать. Недостаток незаменимых жирных кислот, а также нарушения их соотношений, приводят к изменению обменных процессов, понижению естественной резистентности организма. Установлено, что эти жирные кислоты участвуют в биосинтезе ряда биологически активных соединений простагландинового ряда и оказывают влияние на состояние иммунной системы птиц. Продолжаются исследования по определению доступности аминокислот из кормовых средств; уточняются нормы потребностей птицы современных кроссов в доступных аминокислотах и их соотношения в рационах; уточняется соотношение доступных аминокислот, в том числе основных заменимых - глутаминовой и аспарагиновой кислот, к КОЭа в рационах с целью повышения иммуннокомпетентности организма птицы.

В настоящее время в СГЦ «Смена» активно проводятся исследования по созданию отечественного высокопродуктивного кросса мясных кур, маркированных генами медленной и быстрой оперяемости, 
в которых принимают участие специалисты ВНИТИП по кормлению птицы.

Получены результаты тестирования на экспрессию генов медленной и быстрой оперяемости К-к у мясных кур исходных линий и четырехлинейных гибридов-бройлеров.

Проведена оценка транскриптома по отобранным генам медленной и быстрой оперяемости К-к у мясных кур линий Б6 и Б7 и четырехлинейных гибридов-бройлеров на фоне модификаций по составу комбикормов. Проведены исследования экспрессии гена К в разных тканях у кур линии Б-7 с разной скоростью оперяемости. Было установлено, что у кур с медленной оперяемостью (доминантный аллель) экспрессия гена К выше, чем у кур с быстрой оперяемостью. В мышцах крыла эти различия составили 1,59 раза, в селезенке 1,99 раза, в матке 1,54 раза и в слепых отростках 34 раза. Этот факт можно использовать в селекционном процессе для консолидации линии по гомозиготности, однако также интерес представляет экспрессия данного гена у петухов

Получены результаты анализа микробиоты кишечника у мясных кур. Микробное разнообразие слепых отростков представлено семью основными филумами. Было проведено изучение влияния различных рационов на состав микробиоты у цыплятбройлеров. Исследования микробиоты проводили в образцах содержимого слепых отростков цыплятбройлеров кросса Смена-8.

На основе полученных данных и оригинальной математической модели разработан фрактальный портрет микрофлоры кишечника цыплят-бройлеров.

Во ВНИТИП ведется мониторинг содержания микотоксинов в кормах, произведенных в различных регионах РФ, с использованием атомного массспектрометра AB SCIEX TRIPLE QUAD 5500, и изыскиваются способы по снижению токсичности пораженных микотоксинами кормов.

Постоянный рост продуктивности несушек и интенсивности роста мясной птицы диктует необходимость постоянного пересмотра потребности птицы в витаминах.

Все большее значение приобретает аспект повышения витаминной ценности птицепродуктов для человека: доказано, что при повышенном потреблении витаминов птицей повышается и их содержание в птицепродуктах. К тому же содержание витаминов в кормах, несколько превышающее рекомендуемые уровни, обеспечивает улучшение здо- ровья птицы и повышение ее иммунного статуса. Доказано, что некоторые витамины могут играть роль иммуномодуляторов.

На протяжении ряда лет отдел кормления ВНИТИП сотрудничает с ЗАО «Биоамид» (г. Саратов, ген. директор С.П. Воронин) по созданию высокоэффективного минерального премикса для млекопитающих животных и птицы на основе хелатных соединений C L-аспарагиновой кислотой.

Применение органических форм микроэлементов в форме L-аспарагинатов позволяет в 5-7 раз снизить содержание цинка, марганца, меди и кобальта в помете. Последние исследования подтверждают роль ведущих микроэлементов, главным образом $\mathrm{Zn}, \mathrm{Mn}, \mathrm{Cu}, \mathrm{Fe}, \mathrm{I}, \mathrm{Se}, \mathrm{Co}$, в обеспечении здоровья птицы и имеют большое значение с позиций профилактики ряда заболеваний.

Проведены многочисленные исследования по замене кормовых антибиотиков пробиотиками, пребиотиками, фитобиотиками.

Во ВНИТИП ведется поиск дешевых нетрадиционных кормовых средств, которые по биологической ценности не уступали бы дорогостоящим белковым кормам животного и растительного происхождения и могли бы заменить часть зерна в рационе птицы. В этом направлении за последние годы проведена оценка белого люпина, не содержащего алкалоиды, гороха, вики, кормовых бобов, рапса и рыжика с низким уровнем эруковой кислоты и глюкозинолатов, и продуктов их переработки, муки из кератинового сырья, новых источников фосфора и кальция, определено состояние микрофлоры кишечника при использовании в кормах нетрадиционных кормовых средств.

В соответствии с постановлением Губернатора Московской области от 13.03.2012 № 19-ПГ «О ежегодных премиях Губернатора Московской области в сорере науки и инноваций для молодых ученых и специалистов» и на основании решения Совета молодых ученых и специалистов Московской области (протокол от 11.09.2015 № 3-2015) ведущему научному сотруднику ВНИТИП, кандидату сельскохозяйственных наук Егоровой Т.А. была присуждена ежегодная премия Губернатора Московской области в сфере науки и инноваций для молодых ученых и специалистов в 2015 г. Наименование научного труда, за который Татьяне Анатольевне присуждена премия - «Разработка способов повышения эффективности использования нетрадиционных кормов в птицеводстве».

Многочисленные разработки ученых отдела корм- 
ления ВНИТИП запатентованы, опубликованы в книгах и методических рекомендациях. Обобщенные материалы включены в «Руководство по кормлению сельскохозяйственной птицы» (2019) для специалистов птицеводческих хозяйств.

За последнее десятилетие сотрудниками отдела технологии производства продуктов птицеводства разработаны ресурсосберегающие технологии производства яиц и мяса птицы, которые обеспечивают увеличение продуктивности птицы на 5-7\% и позволяют снизить расход кормов на 2-3\%, а затраты топливно-энергетических ресурсов - на 8-10\%. Разработано 7 межгосударственных и национальных стандартов на продукцию птицеводства, комплексная технология производства органических удобрений на основе птичьего помета.

Коллектив ученых отдела осуществляет разработку нового и модернизацию эксплуатируемого в отрасли технологического оборудования для выращивания молодняка и содержания взрослой птицы всех видов. Разработана новая технология выращивания бройлеров на обогреваемых полах. Специалисты отдела принимают участие во внедрении в птицеводческих хозяйствах перспективных технологий и средств механизации производственных процессов.

Сотрудники отдела разрабатывают для птицеводческих предприятий комплексные технологии производства яиц и мяса птицы, модернизацию технологического оборудования, проводят экспертизу и готовят заключения на проекты новых предприятий по производству яиц и мяса птицы, разрабатывают нормы технологического проектирования для птицеводческих предприятий, технологические инструкции и другую нормативно-техническую документацию.

Масштабные комплексные исследований проведены учеными отдела по разработке современных технологий использования светодиодных источников света с применением оптико-волоконных систем. Кратко перечислим отдельные законченные исследования: влияние «холодных» и «теплых» светодиодных ламп белого спектра освещения на жизнеспособность и продуктивность кур промышленного стада; жизнеспособность и продуктивность кур промышленного стада при имитации «восхода» и «заката» солнца на фоне режима прерывистого освещения; рациональный возраст и живая масса кур яичных кроссов с белой окраской скорлупы при начале световой стимуляции; влияние светодиодных источников света с изменяемой цветовой темпе- ратурой на различных этапах «субъективного» дня при прерывистом освещении на жизнеспособность и продуктивность кур; эффективность использования светодиодных источников света с применением оптико-волоконных технологий для локального освещения при клеточном содержании кур; влияние продолжительности «субъективного» дня при прерывистом освещении на жизнеспособность, продуктивность и качество яиц кур.

Разработаны методики: «Методика определения рационального срока продуктивного использования кур-несушек»; «Экспресс-методика определения эффективности производства яиц и мяса птицы»; «Методика ценообразования на пищевые яйца кур». Разработаны и изданы наставления по использованию светодиодного освещения в птицеводстве. Получено 5 патентов РФ на изобретения.

Технология светодиодного освещения внедрена в 277 хозяйствах (установлено 4163 комплектов) в т.ч.: Россия - 256 хозяйств (3824 комплекта, экономия электроэнергии - 103,5 млн. кВт или 414 млн. руб. в год), Беларусь - 12 хозяйств (138 комплектов), Казахстан - 5 хозяйств (187 комплектов), Украина - 4 хозяйства (14 комплектов).

Отделом экономики ВНИТИП в рамках тематических планов проводятся научные исследования по проблемам экономического развития птицеводства. К числу научных направлений относятся исследования, касающиеся: организации и оплаты труда; конкурентоспособности персонала; оценки эффективности функционирования производственной, маркетинговой и финансовой деятельности; системы бюджетирования; системы менеджмента качества и безопасности птицеводческой продукции; системы ценообразования на птицеводческую продукцию; повышения экономической состоятельности птицеводческих предприятий; импортозамещения птицеводческой продукции; рыночного потенциала птицеводческой продукции; бизнес-планирования в птицеводстве и оценки бизнеса отрасли. Эти исследования интегрируются в научнообоснованных предложениях, методических рекомендациях, методиках, имеющих как теоретический, так и прикладной характер.

Отдел совместно с НКО «Росптицесоюз» проводит форумы и семинары по экономическим аспектам развития отрасли птицеводства.

7 октября 2019 г. Правительство Российской Федерации издало распоряжение № 2323-р «О присуждении премий Правительства Российской Федерации 2019 года в области науки и техники для 
молодых ученых». Всего было премировано 5 работ, в том числе ученые ФНЦ «ВНИТИП» РАН совместно с исследователями Уральского федерального аграрного научно-исследовательского центра «Уральского отделения РАН» и ООО «БИОТРОФ» Ленинградской области «За разработку современных технологий для нормализации пищеварения сельскохозяйственных животных, повышения качества животноводческой продукции на основе применения биопрепаратов, альтернативных кормовым антибиотикам, и энтеросорбентов для нейтрализации токсинов кормов». Почетное звание лауреата премии Правительства в области науки и техники получили ученые ФНЦ «ВНИТИП» РАН научный руководитель авторского коллектива, доктор биологических наук, главный научный сотрудник В.Г. Вертипрахов и кандидат биологических наук, ведущий научный сотрудник А.А. Грозина, а также доктор биологических наук А.С. Кривоногова (Уральский ФАНИЦ), кандидат биологических наук биотехнолог Е.А. Йылдырым и кандидат экономических наук Д.Г. Тюрина (ООО «БИОТРОФ»).

Важным событием последнего десятилетия по углублению уровня междисциплинарных исследований стала практика грантовой поддержки - РФФИ, РНФ, Программа Президиума РАН «Инновационные технологии в решении проблем развития агропромышленного комплекса России» и др.

В 2014 г. учеными ВНИТИП и ООО «БИОТРОФ» на конкурсной основе был получен грант Российского научного фонда №14-16-001-40 «Современные представления о микрофлоре кишечника птицы при различных рационах питания: молекулярногенетические подходы».

В ходе выполнения фундаментальных работ по указанному гранту было проведено определение степени воздействия различных типов кормовых добавок на микрофлору ЖКТ яичных кур-несушек и мясных цыплят-бройлеров. Была проведена оценка характера изменений в микробном сообществе ЖКТ кур-несушек в динамике - от вылупления из яйца до взрослого организма.

Полученные результаты, в частности, показали становление микробиологической системы птиц (содержимое ЖКТ в совокупности с населяющей его микрофлорой) уже на стадии эмбрионального развития. При этом микроорганизмы, присутствующие в ЖКТ эмбриона, являются основой, которая определяет формирование стартового кишечного биоценоза вылупившихся цыплят и взрослой птицы. Экспериментальные материалы этих фундаменталь- ных исследований опубликованы в монографии, журнальных статьях, запатентованы в РФ и изложены в ряде рекомендаций и наставлений по кормлению птицы.

На объединенном ученом совете ФНЦ «ВНИТИП» РАН 14 февраля 2020 г. были детально рассмотрены результаты выполнения грантов РНФ, Президиума РАН и планы исследований на 2020 г.

Чисто тезисно остановимся на материалах исследований по грантам.

Научный проект № 16-16-04089 П «Изучение физиологических и микробиологических особенностей пищеварения кур мясных пород в эмбриональный и постэмбриональный периоды для создания новых технологий кормления, обеспечивающих максимально полную реализацию генетического потенциала продуктивности птицы» (научный руководитель - академик РАН И.А. Егоров).

Опыты проведены на мясных курах исходных линий Б6, Б7 и Б8 пород корниш и плимутрок, цыплятах-бройлерах нового конкурентоспособного кросса селекции СГЦ «Смена».

На основе полученных данных и оригинальной математической модели разработан фрактальный портрет микрофлоры кишечника цыплят-бройлеров нового кросса. По результатам исследований 2019 г. получен патент РФ на изобретение. По материалам исследований опубликованы 3 статьи в журналах, индексируемых в базе Scopus, и 3 статьи в журналах из списка ВАК. Поданы тезисы на Всемирный конгресс по птицеводству (Франция, август 2021).

Результаты научных исследований по гранту отмечены дипломом как лучшая научная разработка за 2019 г. на выставке Agros-2020, за монографию «Физиологические и микробиологические особенности пищеварения кур мясных пород в эмбриональном и постэмбриональном периоды для создания новых технологий кормления, обеспечивающих максимально полную реализацию генетического потенциала птицы» 2019 г. (авторский коллектив - И.А. Егоров, В.А. Манукян, И.Н. Никонов, В.Г. Вертипрахов, Т.А. Егорова, А.А. Грозина, Г.Ю. Лаптев, Н.И. Новикова, Л.А. Ильина, Е.А. Йылдырым).

Научный проект № 16-16-04047 П «Создание функциональных яйцепродуктов, оптимизированных по параметрам метаболической адекватности и аллергенности, и комплексной технологии их получения, включающей кормление птицы и переработку полученных яиц с обогащением эссенциальными нутриентами на всех этапах процесса» (научный руково- 
дитель - доктор биологических наук В.К. Мазо).

Проектом предусмотрена реализация алгоритма НИР, включающего биофортификацию комбикормов для кур-несушек, обеспечивающую комплексное обогащение куриных яиц каротиноидами, селеном, витамином E, омега-3 полиненасыщенными жирными кислотами; извлечение полифенольных соединений из ягод клюквы и концентрирование их сорбцией и комплексированием с коагулированным яичным белком; технологию функциональных пищевых ингредиентов (ФПИ) и функциональных яйцепродуктов с низким гликемическим индексом, их апробацию в клинических условиях и соответствующие клинические рекомендации по использованию в профилактическом питании лиц с нарушениями углеводного и/или липидного обмена.

Основные результаты проведенных по гранту исследований: разработаны 4 рациона комбикормов пшеничного типа для производства яиц с повышенным содержанием каротиноидов, селена, витамина Е и омега-3 полиненасыщенных жирных кислот. Проведены исследования по изучению жизнеспособности и продуктивности птицы, затрат кормов на единицу продукции, морфологических и химических качеств яиц кур-несушек при использовании разработанных рационов в СГЦ «Загорское ЭПХ ВНИТИП» на курах промышленного стада кросса «СП-789»; исследовано влияние параметров экстракции и сорбции на содержание и профиль полифенольных соединений (включая антоцианины), извлеченных из ягод клюквы, в составе белковой матрицы - коагулированного яичного белка; разработан новый технологический подход - выделение и концентрирование полифенольных соединений из ягод клюквы целенаправленной сорбцией на коагулированном обогащенном яичном белке для использования в качестве функционального пищевого ингредиента в составе функциональных яйцепродуктов с низким гликемическим индексом; разработан новый технологический подход - концентрирование полифенольных соединений из ягод клюквы комплексированием с яичным белком в ходе тепловой обработки в процессе кислотно-солевого гидролиза яичного белка с одновременным обогащением йодом для использования в составе функциональных яйцепродуктов с низким гликемическим индексом; по результатам анализа нормативных документов, позволяющих отнести продукт к категории «функциональных продуктов», предназначенных для включения в профилактическое питание лиц с нарушениями углеводного и/или жирового обмена, разработано медико-биологическое обоснование (МБО) состава функциональных яйцепродуктов, характеризуемых низким гликемическим индексом.

В период выполнения фундаментальных исследований по гранту издана монография «Функциональные яйцепродукты» (2018), получено 4 патента РФ на изобретения. По результатам НИР в 2019 г. опубликовано 3 статьи в журналах индексируемых в базе Scopus, и 3 статьи в журналах, индексируемых в базе РИНЦ, представлен ряд докладов на международных научных конференциях и форумах.

Данный проект осуществлялся в творческом сотрудничестве с «ФИЦ питания и биотехнологии» (научный руководитель - академик РАН В.А. Тутельян).

Научный проект №17-16-01028 «Изучение механизмов повышения продуктивности и качества мяса бройлеров путем создания легкоусвояемых кормовых компонентов на основе современных физикохимических и биотехнологических способов обработки животного сырья» (научный руководитель академик РАН В.И. Фисинин).

В результате выполнения проекта были разработаны кормовые добавки из кератин- и коллагенсодержащего сырья. В качестве кератинсодержащего сырья использовали бройлерное перо, полученное с линии потрошения птицы. В качестве коллагенсодержащего сырья использовали костный остаток, полученный при механической обвалке птицы. В ходе выполнения проекта был проведен анализ органолептических, физико-химических показателей и показателей безопасности исходного вторичного сырья и кормовых добавок. Разработаны кормовые рационы для цыплят-бройлеров.

Были проведены эксперименты in vivo с применением разработанных кормовых рационов на цыплятах-бройлерах. Определены стандартные показатели птицы, а также физиологический статус, изменение соотношения тканей и костной массы в тушках птицы. Определена характеристика мясного сырья по показателям: безопасность, физикохимические характеристики, в том числе качественный и количественный состав белков, антиоксидантная емкость и органолептические показатели. В результате проведенных исследований было установлено, что применение новых легкоусвояемых кормовых компонентов в рационах бройлеров позволяет повысить продуктивность и качество мяса птицы. Был определен качественный и количе- 
ственный состав белков мяса цыплят-бройлеров, выращенных на различных рационах питания. Фракционирование белковых экстрактов методом двумерного электрофореза 2-DE с последующей массспектрометрией MALDI -TOF/TOF позволило получить до 190 белковых фракций. В ходе исследования были получены протеомные карты 16 образцов мышечных тканей бройлеров. Масс-спектрометрическими методами в них идентифицирован 71 белок, включая несколько тканеспецифичных, которые могут быть использованы как потенциальные биомаркеры при анализе качества мяса птицы.

Практическая значимость проведенных исследований заключается в том, что результаты, полученные в ходе выполнении проекта, могут быть применены в промышленном птицеводстве с целью усовершенствования технологии переработки вторичных продуктов убоя птицы, взамен устаревшей традиционной технологии с использованием вакуумгоризонтальных котлов.

Основными преимуществами новой технологии произ-водства легкоусвояемых кормовых добавок являются: сокращение процесса гидротермического гидролиза с многочасового (6-12 ч) до секундного (60-120 c); возможность перевода кератина пера в усвояемую форму (усвояемость кератина пера повышается с 30 до 85\%, усвояемость белка мясокостного сырья повышается с 35 до 80\%); повышается экологическая безопасность - практически исключается образование дурнопахнущих побочных продуктов и сброс сточных вод; экономия энергии - снижаются энергозатраты при переработке пера в 3 раза, при переработке мясокостного сырья в 1,5 раза.

Новое оборудование установлено и введено в эксплуатацию на птицефабрике ООО «Кузбасский бройлер» (г. Новокузнецк Кемеровской области).

По результатам проведенных в ходе выполнения проекта исследований было опубликовано 8 статей в изданиях, индексируемых в базе данных Web of Science и Scopus; 16 статей в изданиях, индексируемых в базе данных РИНЦ. Получен патент на изобретение № 2700094 «Кормовой продукт для цыплятбройлеров».

Издана монография «Повышение продуктивности и качества мяса бройлеров путем создания легкоусвояемых кормовых компонентов на основе современных физико-химических и биотехнологических способов обработки животного сырья» (2019); авторский коллектив В.И. Фисинин, В.С. Лукашенко, И.П. Салеева, В.Г. Волик, Д.Ю. Исмаилова, С.В. Зиновьев, Е.В. Овсейчик, Е.В. Журавчук, О.В. Гла- зунова, Д.В. Васина, А.В. Исаенко, Г.Ю. Лаптев, Л.А. Ильина, Т.В. Федорова, Н.Л. Вострикова.

Программа «Инновационные технологии в решении проблем развития промышленного комплекса России» (Распоряжение Президиума РАН от 26.12.2018 г.), подпрограмма «Изучение механизмов адаптации систем пищеварения млекопитающих животных и птицы к рационам с различным ингредиентным составом кормов».

В 2019 г. учеными ВНИТИП по данной подпрограмме проводились фундаментальные исследования по теме «Изучение механизмов адаптации системы пищеварения кур к рационам с различным липидным компонентом в корме» (научный руководитель - академик РАН В.И. Фисинин, авторский коллектив - В.Г. Вертипрахов, И.А. Егоров, В.Ю. Титов, А.А. Грозина, Е.Н. Андрианова, И.В. Кислова и др.).

В ФНЦ «ВНИТИП» РАН в отделе физиологии и биохимии (заведующий доктор биологических наук В.Г. Вертипрахов) выполняются исследования по изучению физиологии пищеварения и питания сельскохозяйственной птицы с использованием фистульных методик и изучением процессов пищеварения на молекулярном и клеточном уровне. Наиболее актуальными направлениями исследований являются: изучение развития пищеварения у птиц в эмбриональный и постэмбиональный период; исследование пищеварения у кур и цыплятбройлеров при использовании в рационе биологически активных добавок (ферментов, пробиотиков, органических кислот, фитобиотиков), а также влияние на эти процессы микотоксинов, с изучением новых биохимических маркеров крови для их диагностики; изучение внешнесекреторной функции поджелудочной железы кур при использовании в их рационе различных по ингредиентному составу кормов; исследование регуляции пищеварения при определении активности пищеварительных ферментов и окиси азота в плазме крови кур.

Исследования 2019 г. по вышеуказанной теме наглядно свидетельствуют о том, что секреторная функция поджелудочной железы животных четко адаптируется к липидному составу рациона. У кур при замене жирового компонента в корме изменяется активность амилазы, липазы и щелочной фосфатазы в панкреатическом соке. Следовательно, экзокринная функция поджелудочной железы реагирует на липидный компонент рациона. Полученные результаты будут использованы для нормирования жиров в рационах птицы.

Установлена корреляция между активностью про- 
теаз и щелочной фосфатазы в панкреатическом соке и дуоденальном химусе у кур. Это позволяет предложить к использованию фосфатазно-проте-азный индекс, который отражает процессы адаптации пищеварения к новому компоненту в составе рациона. Указанный индекс может быть индикатором в определении состояния функции поджелудочной железы, пищеварительного канала в медицине, ветеринарии, а также отражать процессы адаптации пищеварительных ферментов к составу рациона.

Разные растительные масла оказывают влияние на все виды обмена веществ, изменяя переваримость сырого жира (самая высокая у рапсового масла), сырого протеина (самая высокая переваримость у подсолнечного и рапсового масла) и сырой клетчатки (высокие показатели у льняного, соевого и рапсового масла). Это является основой разработки оптимальных жировых продуктов для питания птицы.

Биохимические показатели крови курнесушек отражают состояние метаболизма при добавлении в корм разных растительных масел. Наиболее критичные значения отмечаются при использовании льняного и соевого масла. В этом случае наблюдается повышение коэффициента де Ритиса и фосфотазно-

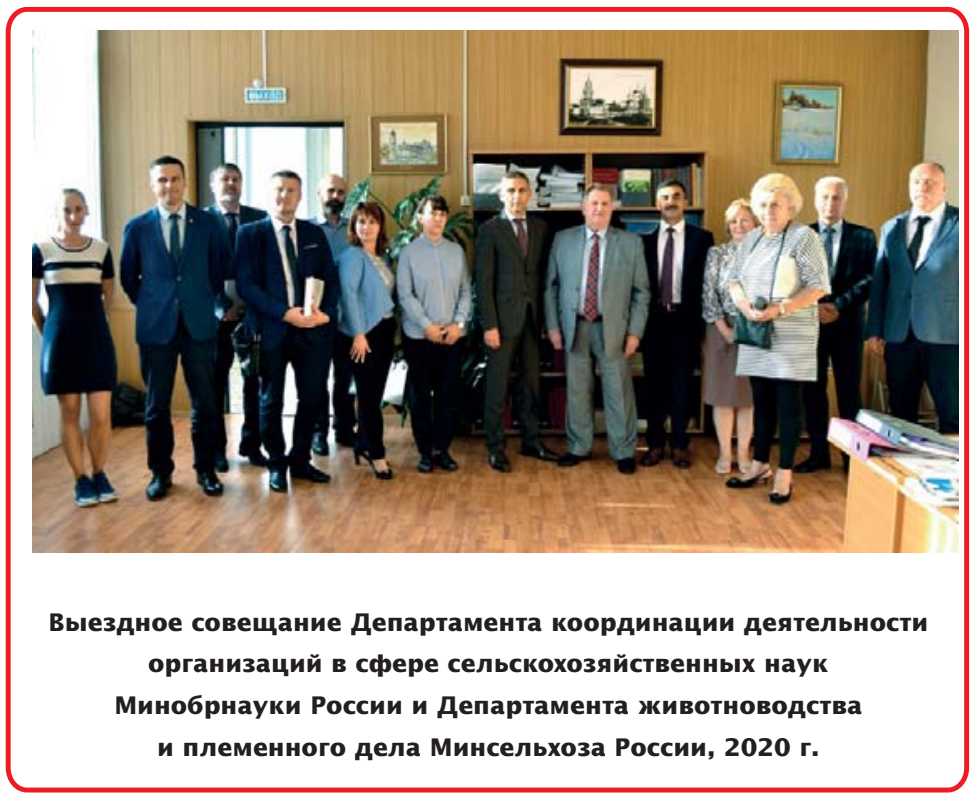
цией поджелудочной железы. Методы хронических опытов на животных имеют высокий научнотехнический уровень, поскольку позволяют «заглянуть» в механизм процесса с учетом нервной и гуморальной регуляции.

По результатам НИР опубликовано за 2019 г.: 1 монография, 3 научных статьи в журналах, индексируемых в базах в Scopus и Web of Science, 4 - в журналах, индексируемых в РИНЦ. Получен патент на изобретение № 2700500 «Способ повышения продуктивности цыплят-бройлеров путем снижения патогенной микрофлоры в кишечнике птицы». Подана заявка на изобретение «Способ оценки адаптации пищеварения птицы к ингредиентному составу рациона» (№ 2019142448 от 19.12.2019).

Материалы научных исследований были представлены на международных конференциях: «Мо- протеазного индекса у кур и цыплят-бройлеров. Указанные индексы могут быть использованы для оценки состояния здоровья пищеварительного аппарата, метаболизма, а также процессов адаптации к различным компонентам рациона.

Установлена корреляция и получена математическая формула между переваримостью протеина и активностью протеаз при использовании в рационе кур подсолнечного и рапсового масла, что позволит в дальнейшем прогнозировать состояние пищеварительной функции по показателям доступности питательных веществ корма.

Результаты исследований являются фундаментальными и указывают на то, что механизм адаптации пищеварения у животных к изменениям в составе рациона связан с внешнесекреторной функ- лекулярная и клеточная биология» (Сингапур, октябрь 2019), XXII Европейский Симпозиум по питанию птицы (Польша, июнь 2019), научно-практическая конференция, посвященная 100-летию со д н я О С н В а н И МГАВМиБ - МВА имени К.И. Скрябина, на тему «Актуальные проблемы ветеринарной медицины, зоотехнии и биотехнологии» (Москва, 2019).

Особо хочется отметить большую организационную работу коллектива ВНИТИП и активное участие ученых в ежегодных выставках: «Золотая осень», «Зерно, комбикорма и ветеринария», «Агрофарм», «Архимед», «Агрос» и др.

Отмечая 90-летний юбилей ВНИТИП, следует отдать дань глубокого уважения всем поколениям ученых и специалистов института, которые внесли весомый вклад в развитие птицеводства России. Но впереди - новые важные задачи, требующие проведения масштабных фундаментальных междисциплинарных исследований и реализации инноваций в производство для обеспечения конкурентоспособности российского птицеводства на мировом уровне. 